\title{
THE CONSERVATIVe AS ENVIRONMENTALIST: FROM GOLDWATER AND THE EARLY REAGAN TO THE 21ST CENTURY
}

\author{
Daniel A. Farber*
}

We often think of conservatives as opposed to environmental regulation. Yet it has not always been so. Conservative icons like William F. Buckley and Barry Goldwater took vigorous public stands in favor of environmental protection, as did Ronald Reagan while he was governor of California. Ronald Reagan shifted to a sharply anti-regulatory stance in the early years of his presidency, but then shifted again to a more moderate position. Reagan personally championed the international ozone agreement and signed a law to require planning for possible climate change. Even today, there are important conservative voices advocating environmental initiatives such as a carbon tax.

This Article recovers the forgotten history of conservative environmentalism. It argues that conservative environmentalism faded largely because of external political forces, such as the influence of the fossil-fuel industry. These forces may weaken due to several trends, opening the door for a more constructive public discourse about environmental policy.

\section{TABLE OF CONTENTS}

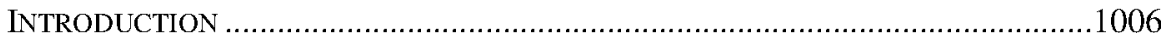

I. INITIAL RESPONSES BY CONSERVATIVES TO ENVIRONMENTAL ISSUES ...........1011

A. William F. Buckley and the Origins of Modern Conservatism..............1013

B. Barry Goldwater's Conservative Environmentalism.........................1016

C. Ronald Reagan's Forgotten Environmentalism..............................1019

* Sho Sato Professor of Law, University of California. I would like to thank Edna Lewis of the Boalt Law Library for her invaluable assistance in locating source material, and Jonathan Adler, Ken Manaster, John Nagel, Sarah Light, Anne Joseph O'Connell, Joseph Tomaine, and John Yoo for their helpful comments on earlier drafts. Given that some of them do not share my perspective, it seems especially important to absolve them of responsibility for the final product and thank them for their generosity in providing detailed comments. 
D. Other Early Conservative Voices ...................................................1022

II. The EClipse of Conservative ENVIRonMENTALISM ..........................1024

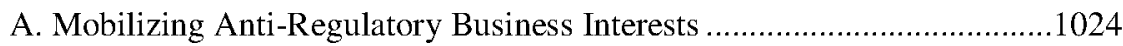

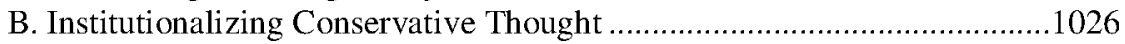

C. Environmental Policy and the Reagan Administration .......................1030

D. Hardening Anti-Regulatory Views After Reagan ...........................1037

\section{EXPLORING THE POTENTIAL FOR A CONSERVATIVE ENVIRONMENTALIST}

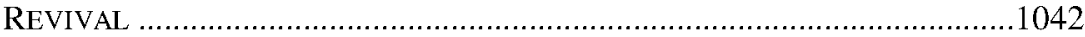

A. A Shifting Economic and Political Base ...................................... 1042

B. Straws in the Wind? Signs of Conservative Environmentalism ...............1050

CONCLUSION

\section{INTRODUCTION}

Today, it may seem more natural to associate conservatism ${ }^{1}$ with opposition to environmental regulation. ${ }^{2}$ Just how far the conservative movement has shifted from its early attitudes on the environment is vividly exemplified by Ronald Reagan's 1972 campaign to preserve the Sierras. Already a leading figure in the conservative movement, Governor Reagan made a dramatic horseback ride

warming:

1. For instance, consider survey evidence about the existence of global

Wide majorities of Steadfast Conservatives $(75 \%)$ and Business Conservatives $(71 \%)$ say there is not solid evidence the Earth is warming - the only two typology groups with a majority who hold this view. Nearly half of Steadfast Conservatives (49\%) say warming is not happening at all, while $25 \%$ say not enough is yet known. Business Conservatives are divided, with about as many saying it is not happening $(36 \%)$ as say that not enough is yet known (33\%).

Beyond Red vs. Blue: The Political Typology Section 7: Global Warming, Environment and Energy, PEw RESEARCH CTR. (June 26, 2014), http://www.peoplepress.org/2014/06/26/section-7-global-warming-environment-and-energy/. According to some observers, "The broad pattern is that climate and energy issues are highly politicized, whereas issues tied to biomedical science, food safety and space policy often are strongly tied to other, nonpolitical, factors." The Public's Political Views are Strongly Linked to Attiudes on Environmental Issues, SCI. NEWS (July 1, 2015), https://www.sciencedaily.com/releases/2015/07/150701114752.htm.

2. In this Article, the term is used as shorthand to identify those who wish to reduce substantially the level of regulation of pollution and development restrictions on public lands and waters. As Jacquelyn Switzer points out, the term anti-environmental is inaccurate to the extent that "it assumes those associated with the label are somehow philosophically 'against' the environment, which is seldom the case." JACQUELYN VAUGHN Switzer, GreEn BaCKLASh: THE History and Politics of EnVIRONMENTAL OpPosition iN THE U.S. 13 (1997). Admittedly, anti-environmental is a slippery term. Nevertheless, it is useful to have a shorthand for "advocates of substantial reductions in regulation of pollutants and in protections of public land against development." 
to announce his success in killing a major federal highway project in the Sierras. ${ }^{3}$ In his inaugural address as governor a year earlier, he proclaimed determination "to preserve the magic beauty of California."4 As Reagan's ride illustrated, conservatives and anti-environmentalism were not always closely associated. In the early days of the modern conservative movement, iconic figures such as William F. Buckley, Barry Goldwater, and Ronald Reagan took outspokenly environmentalist positions. But by 1980 , the earlier environmental enthusiasm of these conservatives had become clouded. Reagan adopted a harshly antienvironmentalist stance in his presidential campaign and in the first years of his presidency, then pivoted again to a more moderate approach-one that included his personal involvement in some environmental initiatives. ${ }^{5}$

This Article seeks to recover the forgotten history of early conservative environmentalism and to understand the turn toward the anti-environmentalism attitudes that now characterize many conservatives. I will suggest that the shift reflected an emergence of a coalition of disaffected westerners and business interests (particularly in the fossil-fuel industry) supported by an interlocking network of foundations, donors, and conservative-policy advocates. Today, antiregulatory views remain dominant, with rejection of climate change as a kind of badge of membership for many to the conservative movement. For instance, conservative political-action committees ("PACs") mounted a successful campaign to defeat Republican Senator Richard Lugar, who had acknowledged the problem of climate change. ${ }^{6}$

Yet this stance is not inevitable. Approaches such as a revenue-neutral carbon tax, ending subsidies to extractive industries, and strong state-level environmental law can be consistent with conservative principles, given conservative belief in markets, federalism, and national security. The carbon tax, in particular, would seem to have a strong conservative foundation: it minimizes expansion of the federal bureaucracy, leaves decisions about emissions reduction to the market, and could displace other taxes rather than swelling government revenues.

In a more a speculative vein, I will suggest that further changes could be in the offing, prompted by social and economic shifts in the West, combined with the increasing economic importance of renewable energy and the decline of coal. These developments may already be weakening some of the pressures that have led conservatives to conform to the current anti-environmental orthodoxy. Dissident conservative voices, though seemingly unaware of the early embrace of

3. See infra text accompanying notes 109-12. A photograph of Reagan on horseback during this ride can be found in JACK FISHER, STOPPING THE ROAD: THE Campaign Against Another Trans-Sierra Highway 96 (2014).

4. Ronald W. Reagan, Governor of Cal., Second Inaugural Address (Jan. 4, 1971), http://governors.library.ca.gov/addresses/33-Reagan02.html.

5. See infra text accompanying notes 229-48.

6. See Coral Davenport \& Eric Lipton, How G.O.P. Leaders Came to View Climate Change as Fake Science, N.Y. TIMES (June 3, 2017), https://www.nytimes.com/2017/06/03/us/politics/republican-leaders-climate-change. 
environmental protection by illustrious predecessors, are calling for a reexamination of conservative approaches to environmental issues, such as taking seriously the idea of a carbon tax. ${ }^{7}$ The Trump presidency may be a setback for these conservative voices, ${ }^{8}$ but it is much too early to draw conclusions about the ultimate impact of the Trump era on conservatism.

Some readers may be tempted to view the history as simply showing how conservatism purified itself over time. This is a difficult argument to refute because it assumes a settled understanding of the true meaning of conservatism. Yet conservatives, while uniting on some crucial policy prescriptions, have never shared a unified intellectual framework. As early as the 1950 s, a leading conservative thinker expressed doubts that there was any conceptual unity in the array of opponents to liberalism. ${ }^{9}$ One historian of modern conservatism describes "five distinct components-libertarians, traditionalists, national security hardliners, neoconservatives, and the Religious Right—each reacting against a perceived external threat from the Left." ${ }^{10}$ Donald Trump's economic nationalism might be considered a deviation from conservatism or, on the other hand, a different form of it. These perspectives are too diverse to distill to a single, coherent political philosophy, so there is no clear answer to the question of whether an ideology has been purified or simply modified.

A similar argument concerns ideology and political parties. Some might say that the current dominance of anti-environmental views among Republicans reflects the party's move to the Right. But again the evidence is ambiguous. Political scientists have largely defined ideology in ways that are difficult to distinguish from changes in political strategy. ${ }^{11}$ And in measuring ideological positions among the electorate, a similar Left-Right scale omits important nuances ${ }^{12}$ : most Americans hold views that do not fit consistently with either ideology, ${ }^{13}$ exemplified by voters with conservative social values who strongly support government spending. ${ }^{14}$ As Cynthia Farina said, "The inquiry into history

7. See infra text accompanying notes 359-406.

8. The Administration has been heavily slanted toward appointees skeptical of climate science, as is the President. See Devin Henry, Trump Stacks Administration with Climate Change Skeptics, HiL (Sept. 9, 2017), http://thehill.com/policy/energyenvironment/349877-climate-skeptics-on-the-rise-in-trumps-epa.

9. George H. Nash, The Conservative Intellectual Movement in AMERICA SINCE 1945, at 175-76 (2006) (quoting Russell Kirk). One source of controversy was over whether Edmund Burke's traditionalist philosophy provided an appropriate basis for conservatism. $I d$. at $173-74$.

10. $I d$. at $578-79$. It seems entirely possible that a similar analysis would show that the Left is united primarily by its opposition to the Right, in which case it would be a mistake to expect much intellectual coherence from either ideological group.

11. See Cynthia R. Farina, Congressional Polarization: Terminal Constitutional Dysfunction?, 115 CoLUM. L. REV. 1689, 1689, 1693, 1699, 1701-02 (2015).

12. See id. at 1707.

13. See id. at 1711 .

14. See id. at 1715,1731 . 
follows what is becoming a familiar theme: [a] seemingly straightforward and discouraging answer becomes, on deeper examination, far more nuanced . . .."15

This Article examines a different strand of American political history but reaches a similar conclusion: what seem like clear-cut ideological differences regarding the environment are part of a more nuanced evolutionary process. History reveals that the founders of modern conservatism did not hold consistently anti-environmental views and sometimes advocated strong environmental protection, deeply at odds with many of their successors. ${ }^{16}$ To the extent that conservatism and anti-environmentalism are viewed as wedded today, that viewpoint does not necessarily reflect any deep logical nexus.

I will suggest that, rather than being a triumph of the "true" conservative ideology, one type of conservative environmental position has prevailed for a variety of more practical reasons: it empowered a link between the Republican Party and business interests; certain anti-regulatory business owners have become crucial funders not only for Republican politicians, ${ }^{17}$ but also for a network of think tanks and academic programs intended to shift the intellectual climate in a conservative direction; and the party has become more tied to rural interests that favor extractive industries. ${ }^{18}$ The Republican Party's increasing ties with resourcebased industries, like oil, have helped cement conservative antienvironmentalism. ${ }^{19}$

15. Id. at 1705 .

16. Consider, for instance, the view of Dick Armey, a later conservative House Majority Leader: "If we don't close down the Environmental Protection Agency, we at least put a snaffle bit on them and ride the pony down. They're out of control." SwITZER, supra note 2 , at 103 .

17. This is exemplified by the role of the Koch brothers' fossil-fuel-based donor network in providing support for aspiring Republican presidential nominees. See JANE Mayer, Dark Money: THE Hidden History of the Billionaires BeHind tHe Rise OF tHE RADICAL RIGHT 302-03 (2016).

18. Despite the loaded language, the following description of the emergence of a conservative ideological business complex is largely accurate:

During the 1970s, a handful of the nation's wealthiest corporate captains felt overtaxed and overregulated and decided to fight back. Disenchanted with the direction of modern America, they launched an ambitious, privately financed war of ideas to radically change the country. They didn't want to merely win elections; they wanted to change how Americans thought.

Id. at 375 .

19. The existence of these political incentives does not necessarily imply selfseeking motives among conservatives. Conservative thinkers with anti-environmental views found themselves supported by a network of businesses and think tanks. They also found themselves embraced by conservative politicians and funders who took anti-regulatory positions. Other conservative views lacked these forms of support. Not surprisingly, given the economic and political setting, certain varieties of conservatism thrived while others fell increasingly by the wayside. By the same token, if the constellation of political, economic, and institutional pressures changes, other versions of conservative thought might suffer less of a competitive disadvantage and might also take hold. Recognizing environmentalism's 
A roadmap of what follows: Part I examines initial responses by conservatives to environmental issues, particularly the stances of Buckley, Goldwater, and Reagan in the 1960s and early 1970s. Part II traces the dramatic (though incomplete) transformation of conservative views by 1980 , a transformation that may have been due to alliances with western and industry allies. Powerful new conservative institutions such as the Heritage Foundation ("Heritage"), whose support was often tied to extractive industries such as fossil fuels, helped embed these anti-environmentalist views in conservative dogma. The result is a strong and mutually reinforcing network of politicians, business interests, and conservative institutions, which is likely to be highly resistant to change. Nevertheless, Part III argues that this existing network may be subject to erosion due to political and economic changes, giving alternative conservative stances an opportunity to spread. Even today, some conservative voices advocate unorthodox measures, like a carbon tax. So far they seem to have made limited headway but, given a different constellation of political and economic forces, that could change.

For purposes of this Article, it is important to distinguish between two different kinds of shifts in conservative views. One possibility is that conservatives could become more moderate in their tactics, in the sense of being more willing to compromise on their principles. ${ }^{20}$ The focus of this Article, however, is another kind of shift: one involving a reinterpretation of conservative principles rather than an increased willingness to compromise those principles for pragmatic reasons. ${ }^{21}$

It is impossible to know whether such a change in conservative views will happen. But the lesson of history is that it is a mistake to identify conservatism with a particular set of policy views that are dominant at any one time. There was a time when conservative leaders took a very different stance on environmental issues. Their positions shifted when political and institutional factors favored a different view, ${ }^{22}$ but those factors could very well change again. Even today there are alternative visions of conservative principles, which may yet gain significant traction within the conservative movement. ${ }^{23}$ If so, perhaps our society will be able

roots in conservative thought could help promote a healthy reexamination of current positions within the conservative movement and could lead to a more productive policy dialogue in the broader public arena.

20. Such moderation would evidence itself in a greater willingness to treat conservative positions as default rules subject to modification based on the facts of individual policy issues. Or, while continuing to think that the best policies are always dictated by strict conservative principles, conservatives might become more willing to compromise to get things done. In short, conservatives could become more pragmatic.

21. Such conservatives may not be willing to compromise their principles, but their principles would be more like those of Reagan, Buckley, and Goldwater in the early days of modern conservatism. In short, rather than becoming more moderate, they might remain staunchly conservative, but with a different take on the environment, changing the nature of what constitutes conservative policies.

22. See infra Part II.

23. See infra Part III. 
to move beyond what has been called bumper-sticker debate on environmental issues. ${ }^{24}$ That should be a welcome prospect for liberals and conservatives alike.

\section{INITIAL RESPONSES BY CONSERVATIVES TO ENVIRONMENTAL ISSUES}

Some background on the emergence of modern environmentalism is necessary to set the stage for considering conservative responses. Although efforts to conserve nature began much earlier, for our purposes we can begin the story in the 1960s. Environmentalism took hold most firmly in urban areas and in certain regions such as the West Coast and New England. ${ }^{25}$ During the 1960s, groups like the Sierra Club expanded dramatically, and there was a spate of new federal legislation, such as the Wilderness Act of 1964 and initiatives dealing with air and water pollution. ${ }^{26}$ In the mid-1960s, President Lyndon Johnson spoke forcefully in favor of environmental protection. ${ }^{27}$ By 1970, the year of the first Earth Day, public support for the environment reached a high pitch. ${ }^{28}$

Johnson's successor was Richard Nixon, an unlikely candidate to be an environmental champion. Resentment of government was an important theme of Nixon's campaign for the presidency, ${ }^{29}$ a theme that continued to reverberate nearly a half-century later in the Trump campaign. ${ }^{30}$ But Nixon took forceful

24. The phrase is from David Roche \& Sara Dewey, Bumper-Sticker Debates: An Introduction to the Symposium "Conservative Visions of Our Environmental Future," 23 DuKE ENVTL. L. \& POL'Y F. 243, passim (2013). As examples, they cite a bumper sticker reading "Reduce Carbon Emissions: Shoot an Environmentalist!" and one in which the $\mathrm{G}$ in "Green" is a hammer and sickle. Id. at 243-44.

25. See Samuel P. Hays, Beauty, Health, and Permanence: Environmental POLITICS IN THE UNITED STATES, 1955-1985, at 41-45 (1987). Although support for environmental protection was bipartisan, Democrats often took the dominant role. JAMES M. Turner, The Promise of Wilderness: American ENVIRONMENTAl Politics Since 1964, at 39 (2012). But ultimately, bipartisan support made possible the tremendous legislative strides of the period. $I d$. at 135 . For more on the emergence of the environmental movement, see Judith A. LAYZER, OPen for Business: Conservatives' OpPosition to ENVIRONMENTAL REGULATION 11, 27-35 (2012).

26. See HAYS, supra note 25, at 53 (Wilderness Act and other preservationrelated legislation).

27. For example, in a 1965 message to Congress, Johnson warned that " $[t]$ he air we breathe, our water, our soil, and wild-life, are being blighted by the poisons and chemicals which are the by-products of technology and industry. . . " LAYZER, supra note 25 , at 33 .

28. See TURNER, supra note 25, at 95-97.

29. See Elizabeth Drew, Richard M. Nixon 21 (Arthur M. Schlesinger, Jr., ed. 2007). Nixon also began the process of driving liberal Republicans out of the party. Id. at 35-36.

30. This resentment was reflected in Trump's calls to "drain the swamp" of Washington. Trevor Hughes, Trump Calls to "Drain the Swamp" of Washington, USA TODAY (Oct. 18, 2016), https:/www.usatoday.com/story/news/politics/elections/ 2016/2016/10/18/donald-trump-rally-colorado-springs-ethics-lobbying-

limitations/92377656/ (Trump denounces the "rigged system the rewards the wealthy and well-connected at the expense of the common man."). 
positions $\mathrm{s}^{31}$ on behalf of the environment in his early years as president. ${ }^{32}$ Nixon was concerned about Senator Ed Muskie as a potential Democratic opponent and wanted to meet this prospective challenge, while also limiting the ability of Democrats to exploit the issue in the off-year congressional elections. ${ }^{33}$ As a biographer puts it, "Nixon loved to confound the enemy. Stealing the Democrats' clothes was Nixon's old Tom Sawyer trick-he had pulled it on Senator Ed Muskie by pushing for environmental laws." ${ }^{34}$ In a major message to Congress, Nixon took an emphatically pro-environmental position and followed up by creating the Environmental Protection Agency ("EPA") and the National Oceanic and Atmosphere Administration ("NOAA"). ${ }^{35}$ In 1970, he signed the National Environmental Policy Act ("NEPA"), the first of a wave of environmental legislation, such as the Clean Air Act, over the next few years. ${ }^{36} \mathrm{He}$ also called for an emissions tax on sulfur dioxide and for a national land-use law. ${ }^{37}$

31. For instance, in his 1970 State of the Union address, Nixon called for urgent action and warned that material wealth is not identical with true well-being. LAYZER, supra note 25 , at 33 .

32. See HAYS, supra note 25, at 58. Elizabeth Drew describes Nixon's environmental policies as having "a strong vein of pragmatism, even opportunism." DREw, supra note 29, at 49. My own impression is that it is difficult to untangle the web of Nixon's motivations to distinguish between his inner demons, political expedience, and public policy. Some of his aides, including John Ehrlichmann (who was later enmeshed in the Watergate scandal), were genuinely pro-environmental. LAYZER, supra note 25, at 37.

33. Richard J. Lazarus, The Making of EnVIRonMental LaW 75-76 (2004). John Ehrlichman's diary reports the need for a "bold stroke" and to "pull the rug from under Muskie," but Nixon also had reservations. Evan Thomas, BEIng Nixon: A MAN Divided 253 (2015). He told Ehrlichman, "In a flat choice between smoke and jobs, we're for jobs... But just keep me out of trouble on environmental issues." Id. Reportedly, he preferred to avoid personal involvement in environmental issues, criticizing negative results and taking credit for positive ones. Drew, supra note 29, at 52. At any given time, his position could be deeply conflicted:

Depending on the audience, he promised to protect big business and the environment. He would proclaim that if the Greens took over, "there won't be any private enterprise, no industry left in America." Then he would privately take aside Chris DeMuth, a twenty-three-year-old White House aide, and tell him to develop an environmental policy-but without consulting the secretary of commerce [who would undermine it].

ThOMAs, supra, at 253. Drew also reports that Nixon only reluctantly signed strong environmental legislation from Congress, but he did sign it. See DREW, supra note 29 at $52-$ 53.

34. THOMAS, supra note 33, at 348 . Nixon is hard to categorize in modern terms. Even as he was in the process of being forced out of office, he proposed a system of universal health care. Id. at 485 .

35. LAZARUS, supra note 33 , at 76.

36. TURNER, supra note 25, at 104. As Turner puts it, "A Democratic Congress and a Republican White House competed for leadership to advance the most far-reaching and comprehensive legislation to address environmental reform." Id. at 104. For a listing of significant environmental legislation (mostly from 1970-1981), see CHRISTOPHER M. Klyza \& David J. Sousa, american Environmental Policy: Beyond Gridlock 33 
Nixon soon began to rethink his environmental policies, and by 1972 he had decided to side more with industry. ${ }^{38}$ Indeed, on his last day in office, he vetoed the EPA's budget. ${ }^{39}$ In the meantime, environmentally protective regulation of public lands had begun to spark a backlash in the West and in Alaska, ${ }^{40}$ which Republicans were able to exploit. Yet, despite Nixon's inconsistent attitudes, he presided over some of the most significant environmental initiatives in history. ${ }^{41}$ In effect, he promoted a major expansion of the federal government while railing all along against big government. ${ }^{42}$ These developments provide the backdrop for understanding the environmental views of the early leaders of the conservative movement.

\section{A. William F. Buckley and the Origins of Modern Conservatism}

The modern conservative movement arose from William F. Buckley's efforts to fuse three strands of conservative thinking: libertarianism, traditionalism, and anti-communism. ${ }^{43}$ Buckley argued that smaller government and freer markets would promote traditional social values and institutions. ${ }^{44}$ His version of conservatism was more radical than that espoused by an earlier generation. The older version was exemplified by Senator Robert Taft, a pragmatic conservative

(Rev. ed., 2013). As Klyza and Sousa note, from 1964 to 1980, Congress passed 22 major environmental laws. Id. at 33, 37.

37. LAYZER, supra note 25 , at 38

38. LAZARUS, supra note 33, at 77. The energy crisis of the early 1970 s also contributed to making environmental protection a lower priority. See LAYZER, supra note 25 , at 40 .

39. LAZARUS, supra note 33, at 78.

40. As Lazarus explains:

So long as the federal government pursued a policy both promoting private commercial exploitation of the public lands and state taxation of those activities, the economic concerns within the western states were dampened. When, however, the federal natural resource laws began in the 1970 s to suggest significant limitations on such exploitation in favor of environmental protection, a political coalition in opposition naturally arose.

Id. at $93-94$.

41. See DREW, supra note 29, at 53.

42. See id. at 59.

43. See E.J. Dionne, Jr., Why the Right Went Wrong: Conservatism from Goldwater to the TEA ParTy And Beyond 3, at 40-41 (2016); NASH, supra note 9, at 148. For a spirited treatment of Buckley's role in the rise of conservatism, see RICK PERLSTEIN, BEFORE THE STORM: BARRY GOLDWATER AND THE UNMAKING OF THE AMERICAN CONSENSUS 71-76 (2001). Lee Edwards attributes Buckley's success to his "extraordinary skill at honoring and integrating the conflicting voices of the conservative choir." LEE Edwards, William F. Buckley JR.: The Maker of A Movement 55 (2010). Another important strand of conservatism, the Religious Right composed of conservative evangelicals, emerged only later. See NASH, supra note 9, at 557-58.

44. See DionNe, supra note 43 , at $40-41$. Among the traditional practices that Buckley supported, unfortunately, was racial segregation, though he later regretted that position. Id. at 45,48 . 
who rejected some but not all of the New Deal. Although "Taft's default position was against governmental action," this was only a presumption. ${ }^{45}$ In reaching decisions, he "immersed himself in data and reached a pragmatic conclusion." 46 For instance, Taft came to believe that his most famous achievement, the TaftHartley Act, was weighted too heavily in favor of management and against unions. ${ }^{47}$ Buckley also rejected another strand of conservatism-the Burkean traditionalism embraced by other prominent conservatives at the time-which stressed the need for continuity and caution in making policy changes. ${ }^{48}$ Instead, Buckley's views echoed those of many present-day conservatives with a combination of libertarianism, religious conservatism, and foreign policy hawkishness. ${ }^{49}$

Buckley also vehemently rejected the conspiracy theories of Robert Welch and the John Birch Society. ${ }^{50}$ Buckley considered Welch irrational, ${ }^{51}$ and he felt that the mainstream media used Welch to "anathematize the entire American right wing." 52 He organized a hard-hitting attack on Welch in the National Review, suggesting that membership in the John Birch Society was an irresponsible act that undermined the conservative movement. ${ }^{53}$

45. Carl T. Bogus, Buckley: William F. Buckley JR. AND THE Rise of AMERICAN CONSERVATISM 30 (2011); see also id. at 37 ("Facts and reasoning trumped ideology. Once he studied an issue, he went where the data and analysis led him.").

46. Id. at 30 .

47. Id. at 31

48. See id. at 112; see also id. at 108-11 (contrasting Buckley's views with those of Russell Kirk and Whittaker Chambers). As Bogus explains:

Buckley was himself a libertarian, even if he had not yet so described himself. He was also what we today call a neoconservative and a religious conservative. Kirk's Burkeanism was incompatible with all three philosophies.

Id. at 111. Although Burkeanism has been submerged as a strand of conservatism by other perspectives, it continues to have adherents. For an explanation of this approach by a more recent Burkean, see Ernest Young, Rediscovering Conservatism: Burkean Political Theory and Constitutional Interpretation, 72 N.C. L. REV. 619 (1994).

49. Bogus, supra note 45, at 111.

50. Id. at 196-98; Alvin S. Felzengerg, A Man ANd His Presdents: The POlitical OdysSSEY OF William F. BUCKLEY, JR. 136-45 (2017). According to Perlstein, the John Birch Society presented Buckley with something of a dilemma: "If political surrealists like Welch ended up in control of the movement, all might be lost. But if National Review lost the Roger Millikens and Adolphe Menjous and couldn't continue to raise enough money to stay in business ...." PerLSTEIN, supra note 43, at 155. Perlstein reports that the decision to repudiate Welch involved a meeting with Buckley, the head of American Enterprise Institute ("AEI") and a close Goldwater advisor, among others. Id. at 156.

51. Id. at 181 .

52. Id. at 189.

53. Id. Buckley was not alone in thinking that the wild conspiracy theories of the John Birch Society were an embarrassment to the conservative movement. See NASH, supra note 9 , at 300-01. To his credit, Buckley also fought vigorously against the anti-Semitism that tainted fringes of the conservative movement. See EDWARDS, supra note 43, at 82-84. 
Similarly, Buckley rejected the ultra-individualist libertarianism of Ayn Rand. Although they shared a libertarian bent, Buckley believed that the individualism was associated with religious faith while collectivism was paired with atheism; whereas Rand was a staunch atheist who considered religion a delusion. ${ }^{54}$ Rand believed fiercely in self-reliance, rational self-interest, and rationality, and saw altruism and religion as barriers to human thriving..$^{55}$ Buckley commissioned a review of her novel Atlas Shrugged by Whittaker Chamber. Chambers denounced Rand's book for espousing an arrogant and ultimately repressive ideology of elite power. ${ }^{56}$ Even today, the National Review continues to publish articles denouncing Rand. ${ }^{57}$

Buckley took some positions that may seem decidedly at odds with today's dominant conservative views. In his 1965 run to be mayor of New York, Buckley took a strongly environmentalist position well before the environmental movement had had any real success in Washington. ${ }^{58}$ Discussing pollution, he said, "Here is a legitimate concern of government-a classic example of the kind of thing that government should do, according to Lincoln's test, because the people cannot do it as well or better themselves." 59

Buckley viewed air pollution as a serious public-health problem: "We all know that air pollution is a contributing cause of respiratory disease - of chronic bronchitis, of pulmonary emphysema, of lung cancer." 60 Buckley called for the city government to reduce its own air pollution, first by retrofitting existing buses and then by replacing them with buses running on liquefied natural gas. ${ }^{61}$ Similarly, Buckley called for improved pollution control on other city vehicles, including police cars and garbage trucks. ${ }^{62} \mathrm{He}$ also wanted to prohibit the burning of bituminous coal, coupled with a mandate for Consolidated Edison, a New York City utility company, to convert to natural gas until it could later switch to nuclear power. ${ }^{63}$ He proposed that all cars sold in the city or entering the city be required to comply with California's new air pollution standards for vehicles. ${ }^{64}$ To reduce traffic, he advocated a toll to discourage cars from entering Manhattan and an elevated bikeway spanning 125 blocks down Second Avenue. ${ }^{65}$

54. BoGUS, supra note 45, at 205.

55. NASH, supra note 9, at 157.

56. See Bogus, supra note 45, at 212-13; FELZEnBerg, supra note 50, at 84-86. Other leading conservatives also attacked Rand. NASH, supra note 9, at 159.

57. See Bogus, supra note 45 , at 221.

58. Buckley was realistic about his chances but serious about his proposals; when asked what he would do if by some chance he were elected, he quipped, "Demand a recount." EDWARDS, supra note 43, at 105.

59. The full text of the speech can be found in WILLIAM F. BUCKLEY, JR., ThE UNMAKING OF A MAYOR 211-16 (1966).

60. Id. at 212.

61. Id. at 211.

62. Id. at 214

63. Id. at $214-15$.

64. $I d$. at 213.

65. BoGUs, supra note 45 , at 275. 
Buckley also advocated for action to address water pollution. He called for new sanitary sewers to reduce overflows from the combined sewer and stormwater system. ${ }^{66} \mathrm{He}$ also called for monitoring of discharges into the water system, with "offenders assessed at a set rate based on the amount of pollutants that enter the water flow." 67

Notwithstanding these views, Buckley was a deeply influential conservative figure whose journal strongly shaped Ronald Reagan's philosophy. ${ }^{68}$ Due to Buckley's intellectual influence, "[c]onservatism was no longer a philosophy about community - a hallmark of Burkeanism; it had become a philosophy of individualism." 69 Yet he seemed happy to embrace a vigorous defense of the environment.

\section{B. Barry Goldwater's Conservative Environmentalism}

Barry Goldwater's 1964 presidential campaign marked the emergence of the modern conservative movement on the national stage: it established institutional structures, rhetoric, ideology, and political strategies, such as mass fundraising efforts, that prevail today. ${ }^{70}$ His campaign also began a long-term transformation of the Republican Party: moderates and liberals were pushed out and delegitimized within the party, while previously Democratic southern whites became Republican mainstays. ${ }^{71}$ One of Goldwater's most famous statements in his 1964 nomination acceptance speech proclaimed that "extremism in the defense of liberty is no vice" and "moderation in the pursuit of justice is no virtue"-lines that were thought by some to be a bow in the direction of the John Birch Society, a hotbed of conspiracy theorists. ${ }^{72}$ Analysts often say that "almost all" of modern conservative views can be found in the Goldwater era. ${ }^{73}$ Goldwater's most famous book was the 1960 Conscience of a Conservative, ${ }^{74}$ which "laid out the new conservative creed boldly." 75

Goldwater sketched his ideas about the environment in his second book, The Conscience of a Majority, in a chapter titled Saving the Earth ${ }^{76}$ As Goldwater

66. Id. at 273 .

67. Id. at 274. Buckley recommended setting the amounts "high enough to encourage purification measures, yet not so high as to drive the polluter from the city." Id.

68. Id. at 339; FELZENBERG, supra note 50, at xvi, 229-58.

69. BOGUS, supra note 45 , at 333.

70. See DIONNE, supra note 43 , at 16 ; id. at 42 (discussing direct-mail fundraising).

71. See DionNE, supra note 43, at 18-19. Perhaps this should not be surprising: conservative thinkers had long been attracted to the South as a model of a stable, traditionbased society and had supported racial segregation on that basis. See, e.g., NASH, supra note 9, at 202-04.

72. BoGUS, supra note 45, at 194-95.

73. See Dionne, supra note 43 , at 39.

74. BarRy Goldwater, THE CONSCIENCE OF A CONSERVATIVE (1960).

75. See DIONNE, supra note 43, at 50. Notably, the National Review vigorously supported Goldwater's candidacy. EDWARDS, supra note 43, at 77.

76. Barry GOLDWATER, THE CONSCIENCE OF A MAIORITY 212 (1970). 
explained, the title was chosen "because the problems confronting mankind in the blue-green planet upon which our moon-walking astronauts looked back add up to just that - a dramatic and all-encompassing task."77 "Our job," he said, "is to prevent that lush orb known as Earth ... from turning into a bleak and barren, dirty brown planet."78 Continuing to paint environmental problems in stark terms, he added, "It is difficult to visualize what will be left of the Earth if our present rates of population and pollution expansion are maintained."79

Turning to the topic of pollution, Goldwater said the issue "should be much more than a political football for aspiring office-seekers or office-keepers." 80 He added that "it is possible to visualize the prospect of the American people having to make some unhappy and large-sized sacrifices in order to preserve their environment." 81 For instance, he said, it could be necessary to crack down on pollution from coal-fired power plants and that in turn might require a sharp reduction in electricity use. ${ }^{82}$ Goldwater also strongly endorsed environmental enforcement, saying that he felt "very definitely that the administration is absolutely correct in cracking down on companies and corporations and municipalities that continue to pollute the nation's air and water." Although he continued, "I am a great believer in the free, competitive enterprise system and all that it entails, I am an even stronger believer in the right of our people to live in a clean and pollution-free environment." 83 Thus, he said, "When pollution is found, it should be halted at the source, even if this requires stringent government action against important segments of our national economy." 84

Goldwater approvingly described Nixon's approach to the problem as requiring "fundamentally new philosophies of land, air and water use" as well as stronger regulation and "expanded government action." 85 Goldwater also applauded stern action against polluters. He applauded criminal indictments brought by the Nixon Administration against "large corporations accused of dumping waste in our waterways and poisonous gases into the air we breathe," and he asked sarcastically why the Democrats had taken so little action on these issues during the many years when they dominated the federal government. ${ }^{86}$

Goldwater was willing to contemplate some major societal changes in order to protect the environment. He asked Americans to confront some fundamental questions:

Will man be able to curb his lust for material luxury?

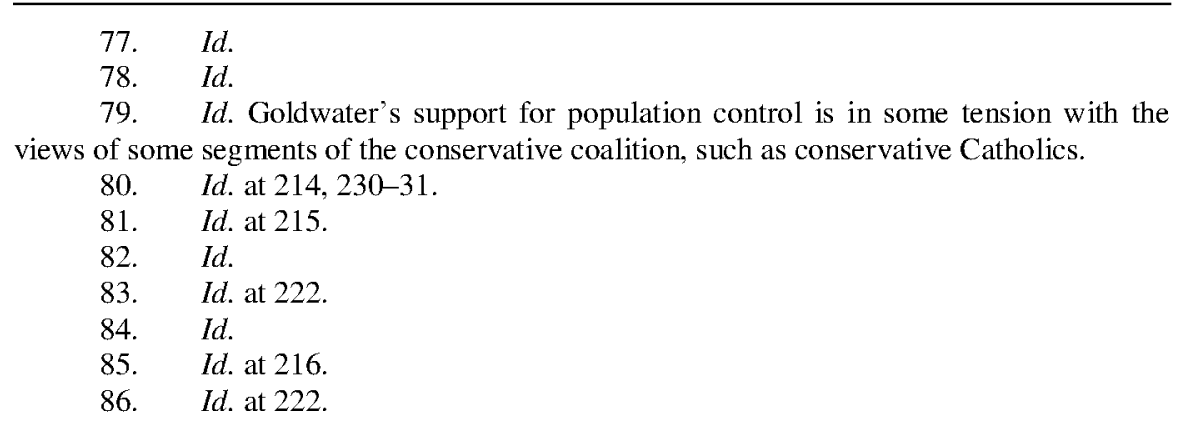


Will man bring himself to accept a substitute for the internal combustion engine, if that proves necessary, or at least a more expensive, less efficient fuel?

Will man be willing to restrict the consumption of electrical power until he is safe and a nonpolluting means of production is found ${ }^{87}$

Goldwater's rejection of consumerism and materialism was not an idiosyncrasy; it was shared by other leading conservative thinkers of the time, such as Buckley and political theorist Russell Kirk. ${ }^{88}$ In explaining his environmental views, Goldwater harkened back to his own experience navigating the length of the Grand Canyon in $1940 .{ }^{89}$ He recalled the small, sandy beaches along the river where his crew gathered driftwood for fires, contrasting that with the current situation where damming had cut off the supply of sediment needed to replenish the beaches. ${ }^{90}$

Goldwater's positions had never been entirely consistent, and his environmentalism could be hit-or-miss. ${ }^{91}$ But The Conscience of the Majority was not an aberration. Goldwater often went camping as a child, and his mother was a nature enthusiast who believed in the religious significance of the natural world. ${ }^{92}$ His feelings about nature and his early work as a photographer in the Grand Canyon motivated him to introduce a bill in 1957 to expand the Grand Canyon National Park. ${ }^{93}$ Then in the 1970s he supported the creation of several wilderness areas. ${ }^{94}$ He voted against the Wilderness Act in 1964, but only, he said, because designation of a wilderness area could trigger a destructive tide of visitors to that area. ${ }^{95}$ When he supported air pollution regulation, personal experience again

87. Id. at 217. The concern about materialism expressed here has echoes in Goldwater's earlier book:

The Conservative believes that man is, in part, an economic, an animal creature; but that he is also a spiritual creature with spiritual needs and spiritual desires. What is more, these needs and desires reflect the superior side of man's nature, and thus take precedence over his economic wants. Conservatism therefore looks upon the enhancement of man's spiritual nature as the primary concern of political philosophy.

GOLDWATER, supra note 74, at 10-11. It is instructive to contrast Goldwater's views of consumption as a human good with those of Donald Trump, whose displays of opulence are a hallmark.

88. NASH, supra note 9, at 240-42. As Nash says, "While libertarians tended to emphasize economic arguments against the State, the new conservatives were more concerned with what they saw as the ethical and spiritual causes and consequences of Leviathan." Id. at 123. For more on Kirk's thought, see id. at 162-63.

89. Id. at 235

90. Id. at 236 .

91. Brian A. Drake, The Skeptical Environmentalist: Senator Barry Goldwater and the Environmental Management State, 15 ENVTL. HIST. 587, passim (2010).

92. Id. at 591. Goldwater's film of the Grand Canyon canoe trip helped make him famous, and his journal from the period shows how much he was moved by what he saw. Id. at 592-93.

93. Id. at 594 .

94. $\quad I d$. at 599.

95. Id. at 596 
played a role-flying into an Air Force base in 1969, he was shocked by a loss of visibility due to smog in the Phoenix area as he attempted to land ${ }^{96}$ As a result, he cosponsored the Clean Air Act in the Senate, and he strongly supported the creation of the EPA, despite his general distaste for federal agencies. ${ }^{97}$

\section{Ronald Reagan's Forgotten Environmentalism}

After Goldwater's overwhelming defeat in 1964, Ronald Reagan became the leading spokesman for the conservative cause. ${ }^{98}$ In a nationally televised speech during the Goldwater campaign, Reagan declared war on what he considered liberal pursuit of socialism, to great conservative acclaim. ${ }^{99}$ Despite opposition from the Goldwater campaign, key Goldwater funders had insisted on putting Reagan on national television for half an hour. ${ }^{100}$ After less than two years as governor of California, Reagan contested Nixon's campaign for the 1968 presidential nomination. ${ }^{101}$

During his campaign for governor of California, Reagan caused consternation among environmentalists when he said a "tree is a tree" regarding the redwoods. ${ }^{102}$ Nevertheless, Reagan has been called "the most environmental governor in California history-protecting wild rivers from dams, preserving a Sierra wilderness by blocking highway builders, creating an air resources board

96. Id. at 597. Goldwater told a friend: "I could go on and on about this, Charlie, as you can well imagine ... . The destruction of our clean air has me really concerned." Id.

97. See id. at 598. By the time of his death, according to Drake, "[o]n green issues as on others, Goldwater now seemed to be leaning distinctly to the liberal wing of his party, an environmental maverick repudiating part of the very political legacy he had helped to create." Id. at 604.

98. Despite the electoral loss, the Goldwater candidacy was a watershed for the conservative movement:

[S]ometimes you win by losing. Goldwater's presidential bid enabled him to raise issues and propose conservative solutions to those issues; to forge a national political organization that would be used by future conservative candidates; to establish for conservatives a broad financial base stemming from direct mail and television appeals; and to demonstrate that a political force called conservatism could nominate a conservative and capture millions of votes.

EDWARDS, supra note 43, at 99.

99. See DionNe, supra note 43 , at 21.

100. Id. at 59 .

101. See id. at 71. By the time of his election, Reagan was already considered an "unapologetic conservative" in the same category as Barry Goldwater, see EDWARDS, supra note 43, at 93, making his support for environmental protection as governor all the more noteworthy.

102. Lou Cannon, Governor Reagan: His Rise to Power 177 (2003). Reagan was actually attuned to other aspects of nature but had a blind spot regarding redwoods. $I d$. at 300 . Nevertheless, Reagan was eventually persuaded to support the creation of Redwoods National Park. Id. at 301-02. In any event, Reagan seemed somewhat embarrassed by this quote and as governor hastened to tell his newly appointed Natural Resources Secretary that it had been taken out of context. See FISHER, supra note 3, at 85. 
that led to the nation's first auto smog controls." 103 This may be an overstatement, but there were indeed some major environmental achievements, as we will see below. And the "tree is a tree" statement was a bit misleading. Reagan was attuned to other aspects of nature, partly because of childhood experiences along the Rock River in Illinois and because of his experiences filming movies in the West. ${ }^{104}$

Reagan's Appointments Secretary, who considered strong California appointments key to Reagan's presumed later presidential bid, identified Norman ("Ike") Livermore as Natural Resources Secretary. ${ }^{105}$ Livermore was in the lumber industry, but also belonged to the Sierra Club. ${ }^{106}$ Reagan was attracted by Livermore's career as a conservationist businessman, and Livermore was the only member of Reagan's California cabinet to serve the full eight years of his gubernatorial term. ${ }^{107}$ With Livermore's support, Reagan compiled an impressive list of environmental accomplishments as governor.

One of Reagan's accomplishments was safeguarding Lake Tahoe from impacts from surrounding development efforts. Reagan agreed that an interstate solution was required after seeing the lake's condition. He signed a compact with the governor of Nevada establishing a joint regional planning authority. ${ }^{108}$

Another particularly dramatic example of Reagan's environmentalism involved the Sierra ride described at the beginning of this Article. Consider this L.A. Times account of Reagan's effort to block a freeway:

A high-speed, trans-Sierra highway between the John Muir and Minarets wilderness areas long had been the dream of Central Valley interests ....

Reagan galloped out of Red's Meadow near Devil's Postpile, 100 packhorses in tow. We overnighted in small tents at a High Sierra lake. The next morning, the governor rode to a meadow beneath the Minaret Summit, dismounted and announced that he had persuaded the Nixon administration not to build the highway's planned initial leg.

But to bury the road idea forever, Reagan proposed joining the two wilderness areas. Congress later agreed. And today, the John Muir

103. George Skelton, Reagan Would Be Amused and Troubled by this GOP Field, L.A. TIMES (Sep. 14, 2015), http://www.latimes.com/local/politics/la-me-pol-prez-capreagan-debate-20150914-column.html.

104. CANNON, supra note 102, at 303. As Cannon says, "When it came to the environment, [Reagan] was a study in contradictions, much like the West he loved." Id. Some of the contradictions may have been due to Reagan's sympathy for farmers and ranchers, since he had owned several ranches and identified with their interests. Id. at 305 .

105. Id. at 177 .

106. Id. Livermore does not seem to have been politically liberal, having chaired a conservative Republican's campaign for Congress. Id. at 178.

107. $\quad I d$. at 299.

108. Id. at $306-07$. 
Trail remains unbroken for 250 miles between Yosemite and south of Mt. Whitney. ${ }^{109}$

In his speech in the Sierras, Reagan charged that a highway crossing "would do irreparable harm to the wilderness beauty and wildlife of the area" and that some species of wildlife in the surrounding area "are becoming endangered and cannot tolerate any further human disturbance." 110 By merging two wilderness areas, he said, "we can prevent the creation of a high-speed trans-Sierra highway through this area for all time and preserve the vast primitive beauty of this wilderness for generations of Californians to come." 111 In another example of Reagan's interest in wildlife, he rejected a proposal by his cabinet members to authorize ranchers to shoot eagles to protect livestock, saying that he would rather have the state pay for lambs killed by eagles. ${ }^{112}$

There were other examples of Reagan's efforts to protect nature. He blocked dam proposals on the Eel River and on the Middle Fork of the Feather River. ${ }^{113}$ Perhaps more notably, he signed California's Wild and Scenic Rivers legislation. ${ }^{114}$ During the Reagan years, California also added 145,000 acres of land, along with areas of the Pacific Ocean, to its state park system. ${ }^{115}$ And even more notably, Reagan signed the California Environmental Quality Act, which has been a thorn in the side of development interests ever since. ${ }^{116}$

Then, as now, Southern California was known for its smog. A historian of his governorship refers to Reagan as a "reluctant but moderately successful warrior" against air pollution in Los Angeles. ${ }^{117}$ Reagan took a number of strong, if only partially successful, steps to deal with pollution. He signed the MulfordCarrell Act, combining the Bureau of Air Sanitation and the Motor Vehicle Pollution Control Board to create the California Air Resources Board ("CARB"). ${ }^{118}$ Reagan appointed as the first head of CARB a prominent California Institute of Technology chemist who had been responsible for linking smog to automobile emissions. ${ }^{119}$ By all accounts, this "stubborn Dutchman" was a

109. George Skelton, The Man in the White Hat Who Saved the Sierra, L.A. TIMES (July 28, 1997), http://articles.latimes.com/1997/jul/28/news/mn-17071.

110. CANNON, supra note 102, at 318-19.

111. FISHER, supra note 3, at 100.

112. CANNON, supra note 102, at 303.

113. Id. at $299-300$.

114. Id. at 315 .

115. Id. at 317 .

116. For an introduction to the statute, see A Summary of the California Environmental Quality Act, CAL. DEP'T OF FISH AND WILDLIFE, https://www.wildlife.ca.gov/Conservation/CEQA/Purpose (last visited Oct. 10, 2017).

117. CANNON, supra note 102, at 307.

118. California Air Resources Board, History of Air Resources Board, https://www.arb.ca.gov/knowzone/history.htm (last visited Oct. 10, 2017).

119. James N. Pitts, Jr. \& Edgar R. Stephens, Arie Jan Haagen Smit: 1900-1977, $\begin{array}{lllll}\text { J. AiR. POLlution } & \text { CONTROL } & \text { ASs } N \text {, }\end{array}$ https://www.arb.ca.gov/research/hsawards/japcaarticle1978.pdf (memorial essay). 
dedicated and successful champion of pollution control in his years at CARB. ${ }^{120}$ During Reagan's term as governor, CARB set air quality standards for stationary sources, such as power plants, and adopted the nation's first nitric-oxide standard for vehicles. ${ }^{121}$

Despite his strong environmental record in California, Reagan was able to "establish[] himself as the undisputed leader of the conservative movement" and "the most popular figure in his party" in 1976, only a year after the end of his environmentally oriented governorship. ${ }^{122}$ True, his record did not please all conservatives, and a small group attempted a recall vote in $1971 .{ }^{123}$ Yet conservatives as a group seemed unfazed by his record as an environmentalist, and when he ran for president in 1980, he was considered "very nearly the perfect conservative candidate - charismatic, articulate, experienced, and principled." 124

\section{Other Early Conservative Voices}

During this early period, like later on, conservative views on environmental issues were not monolithic. Some had less positive views of some environmental protections or of environmentalists as a group. Ayn Rand was perhaps the most outspoken critic of environmentalism.

Despite her anti-religious views and celebration of egoism, Ayn Rand has remained a highly influential figure on the Right. ${ }^{125}$ House Speaker Paul Ryan, for instance, told a gathering of Rand followers that Rand's book Atlas Shrugged "inspired me so much that it's required reading for all my interns and my staff." 126 Rand was starkly opposed to environmentalism. She believed the environmentalists wanted to destroy technology and capitalism, ${ }^{127}$ and her solution to pollution was that people who did not like smog should move elsewhere. ${ }^{128}$ "Nobody can order a person to live in Los Angeles or New York City," she said,

120. Id.

121. See generally Key Events in the History of Air Quality in California, CAL. AIR RESOURCES BOARD, https://www.arb.ca.gov/html/brochure/history.htm\# (last visited Oct. 10, 2017).

122. See DionNe, supra note 43 , at 78 .

123. $\quad I d$. at 91 .

124. See EDWARDS, supra note 43, at 134. Reagan was also close to Buckley, both before and after his presidency. See id. at 134-41.

125. Rand has been particularly appealing to college students. See NASH, supra note 9 , at 241 n.21.

126. DiOnNE, supra note 43 , at 373.

127. Taylor M. Bailey, Ayn Rand's Rejection of Environmentalism: Toward Challenging Right-Wing Inaction on Environmental Issues in the United States 7 (Apr. 9, 2015) (unpublished Distinction Paper, Otterbein University), http:/digitalcommons.otterbein.edu/cgi/viewcontent.cgi?article=1012\&context=stu_dist.

Rand was not entirely consistent, however, since she elsewhere allowed for collective solutions to problems like urban overcrowding and urban pollution. $I d$. at 28 .

128. Id. at 15 . 
so "[i]f some place is bad for your health, you shouldn't live there." 129 She contended that what she called the anti-industrial revolution led by environmental groups was aimed at "the destruction of the remnants of capitalism in today's mixed economy, and the establishment of a global dictatorship." ${ }^{130}$ Although she admitted that air and water pollution are not "good for men" and might warrant some collective response, she thought that ultimately only technology could provide the answer. ${ }^{131}$

Milton Friedman provided a different libertarian perspective. In his 1962 book, Friedman pointed to pollution as an obvious case of market failure: "The man who pollutes a stream is in effect forcing others to exchange good water for bad." 132 Although the downstream landowners might have been willing to agree to this in return for compensation, "it is not feasible for them, acting individually, to avoid the exchange or to enforce appropriate compensation." 133 Thus, Friedman fully supported limitations on polluters.

Friedman's views about government property ownership were more complex. As examples of justified government activity, he pointed to highways (though not limited-access freeways, which could be set up as toll roads) and city parks. ${ }^{134}$ On the other hand, because national parks had controlled entrances where they could charge for admission, Friedman argued that those parks should be in private hands: "If the public wants this kind of an activity enough to pay for it, private enterprises will have every incentive to provide such parks." 135 Friedman influenced Richard Nixon's thinking ${ }^{136}$ among others. ${ }^{137}$

Thus, conservative views were multi-hued during the era of environmental conservatism. Some, like Rand, seemed profoundly disturbed by environmentalism, while others, like Friedman, thought that protection of natural areas should be left to the market-though both seemed to acknowledge that some kind of collective response to pollution problems was warranted. But what is striking in retrospect is that these voices were distinctly at odds with those of prominent conservative leaders like Reagan at that time.

129. Id. at 15-16. Rand projected that environmentalism would lead to a world without cars, rationing of electricity, and only one light bulb per room. Id. at 16 .

130. Id. at 22 .

131. Id. at 36 .

132. Milton Friedman, Capitalism And Freedom 30 (1962). On Friedman's important role in the conservative movement, see NASH, supra note 9, at 433-58.

133. FRIEDMAN, supra note 132.

134. Id. at $30-31$.

135. Id. at 31 .

136. See Thomas, supra note 33, at 143. For instance, Nixon was attracted to Friedman's proposal of a negative income tax to replace government welfare programs. Id. at 206-07. Nixon was also a student of Edmund Burke. Id. at 208, 251.

137. See LAYZER, supra note 25, at 62 (explaining how Nixon's support of emissions tax was championed by conservative economists). 


\section{THE ECLIPSE OF CONSERVATIVE ENVIRONMENTALISM}

Today's environmentalists may view opponents of regulation as a united force (if not a conspiracy of sorts), but this is an oversimplification. ${ }^{138}$ Instead, the opponents constitute a network of business interests, wealthy individuals, think tanks, and politicians.

In this Part, we will see how these actors have sought to counter the 1970s expansion of environmental protection in a mutually reinforcing, though not always united, effort. During the same period, conservatives like Reagan swiftly revised their positions. We begin by considering the response of the business community to the new regulatory regime, then the emergence of today's apparatus of conservative think tanks, and finally, the responses of conservative political leaders such as Reagan and his successors.

\section{A. Mobilizing Anti-Regulatory Business Interests}

Although the federal government's involvement in environmental issues was increasing by the mid-1960s, ${ }^{139}$ it was the 1970 s flood of new legislation that created a dominant federal presence on issues such as air pollution, water pollution, and toxic chemicals. ${ }^{140}$ The bipartisan nature of much of this legislation seems startling today. For instance, the Endangered Species Act passed the Senate unanimously and the House with a 325 vote margin (336-11). But this era of vigorous legislative activity came to an end shortly after the 1970s. ${ }^{141}$

As one historian puts it, the initial surprised attitude of business leaders toward the environmental movement "turned to incredulity and fright" as new legislation went into effect. ${ }^{142}$ Trade associations and their nonprofit research and education centers took an active role in resisting regulation. ${ }^{143}$ In reaction to the new regulatory strictures of the Nixon period, "business began to embrace much harder anti-government positions." 144 The emphasis initially was on potential job losses but shifted by the mid-1970s to claims of excessive cost. ${ }^{145}$ In response to the new regulatory climate, businesses created the Business Roundtable, breathed new life into the Chamber of Commerce and National Association of Manufacturers, founded numerous PACs, and increased lobbying dramatically. ${ }^{146}$ Parts of the business community, especially in manufacturing and resource

138. See SwITZER, supra note 2, at xiii-xiv (speaking of "a complicated and complex movement that is more diverse than many observers have recognized"). Switzer sees considerable diversity even among groups in the same geographic areas opposing the same government policies. See id. at xvi.

139. Joseph Petulla, American Environmental History 411-16 (2nd ed. 1988).

140. Id. at 416-30.

141. KLYZA \& SOUSA, supra note 36 , at 13.

142. HAYS, supra note 25, at 303.

143. See id. at 310-11.

144. DiOnNE, supra note 43 , at 247.

145. See HAYs, supra note 25, at 313.

146. LAYZER, supra note 25, at 50. 
industries like mining and petroleum, soon established a symbiotic relationship with conservative thinkers. ${ }^{147}$

The alliance between conservative businessmen and movement conservatives can be seen as early as the 1960 s, when Fred Koch (father of today's Koch brothers) ordered copies of The Conscience of a Conservative for every library and newspaper in Kansas. ${ }^{148}$ By the time Reagan left office, the Koch family had also launched the Cato Institute, which "promoted the purest strands of libertarian thinking." 149

A memo by soon-to-be Justice Lewis Powell for the U.S. Chamber of Commerce "became a manifesto for the new business activism." ${ }_{150}$ Shortly before going on the bench, Powell wrote this influential memo at the behest of the Chamber of Commerce, ${ }^{151}$ decrying what he considered an anti-capitalist intellectual climate and calling for an organized effort by business to exercise more influence within universities and in public discourse. ${ }^{152}$ According to Powell, "No thoughtful person can question that the American economic system is under broad attack," including voices from campuses, the media, and politicians. ${ }^{153} \mathrm{He}$ singled out social scientists as particularly "unsympathetic to the enterprise system," 154 and he called for the creation of cadres of more sympathetic scholars under the auspices of the Chamber of Commerce. ${ }^{155}$ The Powell memo received considerable attention from conservative elites. ${ }^{156}$

While the Powell memo was a significant reflection of the mood of much of corporate America, it did not reflect a coordinated response by business to the new regulations. As one environmental historian puts it, business "resistance to environmental regulation developed slowly, incrementally, and somewhat haphazardly as each affected industry group felt the impact of the legislative and regulatory process at different points in time." 157 Moreover, she continues, the opposition by the business community "has rarely been united because it mirrors the variations in resources among the various organized interests themselves,"

147. Id. at 52 .

148. See DiONNE, supra note 43 , at 51.

149. See id. at 90 .

150. See id. at 247

151. On the significance of the memo, see LAYZER, supra note 25, at 52. The text of the memo can be found in the Powell archives. Lewis F. Powell, Jr., Attack on Free Enterprise System (1971), http:/law2.wlu.edu/deptimages/Powell\%20Archives/ PowellMemorandumPrinted.pdf.

152. See Thomas O. MCGarity, Freedom to Harm: The Lasting Legacy of THE LAISSEZ FAIRE REVIVAL 41-42 (1st ed. 2013).

153. Powell, supra note 151 , at 2.

154. $\quad I d$. at 4.

155. Id. at 5 .

156. Jason Stahl, Right Moves: The Conservative Think Tank in American Political Culture Since 1945, at 62 (2016).

157. SwITZER, supra note 2, at 105. 
resulting in a lack of cohesiveness. ${ }^{158}$ Individual industries independently pursued their own lobbying and litigation agendas. ${ }^{159}$

One important outgrowth of this reaction was the Sagebrush Rebellion, a western movement that called for massive transfers of federal lands to the states. ${ }^{160}$ This movement drew grassroots support from ranchers and farmers, who regarded environmental protection laws as a potential threat to their business interests. ${ }^{161}$ For instance, farm groups were alarmed by the transfer of pesticide regulation from the producer-friendly venue of the Department of Agriculture to the environment-friendly EPA. ${ }^{162}$

It is important not to oversimplify the response of the business community and its relationship with the conservative movement. ${ }^{163}$ Large multinationals were more concerned about uncertainty in future regulatory costs than the absolute level of costs, whereas small business were generally more worried about impacts on their checkbooks. ${ }^{164}$ Moreover, the interests of different industries were not always aligned. ${ }^{165}$ Nevertheless, organizations such as the National Association of Manufacturers provided a forum for anti-regulatory activities by broad swathes of industry. ${ }^{166}$ As shown in the next Section, their influence on conservative thought was amplified by a series of new institutions.

\section{B. Institutionalizing Conservative Thought}

The influence of conservative thinkers was due not only to their writings but also to "networks of influence with political impact." 167 As one environmental

\section{Id. at 106}

159. See id. at 106-15.

160. LAYZER, supra note 25 , at $88-89$. One example of the influence of this movement was a bill passed by the Nevada Legislature in 1979 maintaining that federal ownership of public lands was unconstitutional. See SwITZER, supra note 2, at 171. A related movement among ranchers and farmers emphasized property rights rather than states' rights. See id. at 247-76 (discussing Property Rights movement). Switzer concludes that the "policy impact of business groups and industry interests is quite different from that of the grassroots groups," with business being more effective in the policy arena. Id. at 282.

161. See HAYS, supra note 25, at 288-90.

162. See id. at 295.

163. As Switzer explains:

Even with their advantages, however, industry has not been an implacable foe for the advancement of the environmental movement's objectives, often because business' demands are highly individualized and fragmented. While some coalitions have been forged, disputes over clean air or water legislation often pit one industry against another, with little agreement on the appropriate path of redress.

SwITZER, supra note 2, at 283-84. In addition, Switzer sees divisions between western natural-resource interests and eastern industrial interests. Id. at 285.

164. See LAYZER, supra note 25, at 54.

165. Id.

166. See SwITZER, supra note 2, at 115-17.

167. NASH, supra note 9, at 26. Of course, there were also networks of support for environmental protection on the other side. LAYZER, supra note 25, at 45 . 
historian puts it, environmental law "spurred a massive infusion of cash from a temporarily united business community, as well as from conservative individual foundations," which "financed the development of a conservative policy infrastructure comprising think tanks and lobbying organizations." 168

The anti-regulatory movement led to the establishment of major Washington think tanks. ${ }^{169}$ The American Enterprise Institute ("AEI") had been created years earlier by the chairman of the country's largest asbestos manufacturer, ${ }^{170}$ but its budget increased tenfold during the 1970s. ${ }^{171}$ According to its website, "AEI's purposes are to defend the principles and improve the institutions of American freedom and democratic capitalism - limited government, private enterprise, individual liberty and responsibility, vigilant and effective defense and foreign policies, political accountability, and open debate." ${ }^{172}$ AEI developed close links with the Goldwater campaign, as did the Hoover Institution, another established conservative think tank. ${ }^{173}$

Other major libertarian foundations were the products of wealthy businessmen such as William Simon, Joseph Coors, and the Koch brothers, along with Mellon heir Richard Scaife. ${ }^{174}$ Notably, the Koch donor network has been dominated by wealthy individuals from the fossil-fuel industry. ${ }^{175}$ The link between conservative environmental views and the fossil-fuel industry is an issue that we will return to later.

Besides AEI, another key player was Heritage, ${ }^{176}$ which bills itself as promoting "conservative public policies based on the principles of free enterprise,

168. Id. Switzer also discusses funding by conservative foundations, while noting that environmental groups, too, benefitted from considerable foundation funding. SwITzER, supra note 2, at 143.

169. NASH, supra note 9, at 139 . These think tanks were partly a reaction to what conservatives saw as overwhelming liberal dominance of the academy. $I d$.

170. See id. at 50-51.

171. LAYZER, supra note 25, at 48.

172. See American Enterprise Institute for Public Policy Research, AEI (2016), https://www.loc.gov/item/lcwa00092806. At its inception, AEI was oriented toward conventional policy analysis. See STAHL, supra note 156, at 30, 35. AEI received a large influx of funding in the early 1970s from Richard Scaife, based on the argument that it would serve as a counterweight to liberal-oriented organizations such as the Brookings Institution. See id. at 55.

173. The Hoover Institution was another early conservative effort, which originally focused on study of the Soviet Union but moved toward more freewheeling conservative advocacy. $I d$. at 36-38.

174. MCGARITY, supra note 152, at 39-40. Scaife's foundation gave over $\$ 500$ million to support conservative institutions. $I d$. at 39 . Scaife and the Koch brothers also provided important financial support to the Tea Party movement years later. Id. at 287.

175. MAYER, supra note 17, at 200-05. Another think tank, the Political Economy Research Center, which focused on environmental issues, was funded by other conservative foundations and industry, including a major coal company. See C. BRANT SHORT, RonALD Reagan AND the Public Lands: AmericA's Conservation Debate, 1979-1984, at 82-83 (1st ed. 1989).

176. See MCGARITY, supra note 152 , at 51-52. 
limited government, individual freedom, traditional American values, and a strong national defense." ${ }^{177}$ From the start, Heritage avoided the kind of scholarly inquiry found in earlier conservative think tanks, and instead aimed at producing fastresponse position papers for immediate use in the political arena. ${ }^{178}$ Heritage and AEI provided key staff for the Reagan Administration and later for the George W. Bush Administration, while also providing homes for conservatives such as Robert Bork and Antonin Scalia between stints in government. ${ }^{179}$ Both foundations experienced surges of funding in the mid-1970s, ${ }^{180}$ but Heritage outdid AEI in funding by developing a new model of politically engaged, less academic activity. ${ }^{181}$

Other important think tanks included the libertarian Cato and Manhattan Institutes. ${ }^{182}$ Illustrating the close connections between the think tanks and conservative politicians, the Mercatus Center at George Mason University was funded with Koch money and initially headed by the wife of Senator Phil Gramm and held regular briefings for congressional staff. ${ }^{183}$ These think tanks, publishing their own journals and providing a home for staff researchers and adjunct fellows, ${ }^{184}$ provided a fount of easily digested briefing papers and press interviews to support libertarian positions. ${ }^{185}$

A key source of support for academic conservatives was the Olin Foundation, established by a prominent gun manufacturer. ${ }^{186}$ In 1977 , William Simon became head of the foundation with the goal of changing public attitudes on regulation. ${ }^{187}$ Some may know of the Olin Foundation's role in launching the law and economics movement in American law schools; ${ }^{188}$ fewer may know that the foundation "quietly served as a money-laundering operation for the Central Intelligence Agency (CIA), steering almost two million CIA dollars to the Vernon Fund and the American Enterprise Institute as part of a covert effort to "combat the influence of communism upon artists, writers and intellectuals in the western

177. See About Heritage, HERITAGE FoundatION, http://www.heritage.org/aboutheritage/impact (last visited Oct. 10, 2017). Heritage played a critical role, particularly in the Reagan era. "Established in 1973, the Heritage Foundation became in the 1980s the nerve center of the 'Reagan Revolution.' Far more than a conventional think tank, the foundation ... deliberately assumed the role of facilitator, liaison, and clearinghouse for the entire conservative public policy network." NASH, supra note 9, at 563.

178. STAHL, supra note 156, at 73. According to Stahl, although Heritage engaged in such traditional activities as holding conferences and issuing policy reports, these activities "were designed to influence legislation in a more conservative direction as rapidly as possible" rather than produce rigorous results. $I d$. at 75 .

179. See MCGARITY, supra note 152, at 50, 52.

180. STAHL, supra note 156 , at $80-81$.

181. Id. at 89-90.

182. MCGARITY, supra note 152 , at 52-53.

183. Id. at 54

184. SWITZER, supra note 2, at 154.

185. MCGARITY, supra note 152, at 54-55.

186. Id. at 38 .

187. LAZARUS, supra note 33, at 95.

188. MAYER, supra note 17 , at 107-09. 
democracies." 189 Olin also funded influential books such as More Guns, Less Crime ${ }^{190}$ a project that must have been dear to the donor's heart.

These think tanks have had considerable impact. Republican administrations drew officials from the think tanks, but the think tanks also provided homes for influential officials during times when Republicans were out of office. ${ }^{191}$ Even today, these think tanks are said to be appealing points of entry into positions of influence by young conservatives beginning their careers. ${ }^{192}$ Their staff members are often treated by the media as equivalent to academic experts; producing books, articles, and policy papers; making media appearances; and publishing opinion pieces. ${ }^{193} \mathrm{~A}$ study of climate denial books found that over $90 \%$ published before 2005 had links to conservative think tanks, ${ }^{194}$ while a follow-up study found that from 2000 to $2010,87 \%$ of books from such publishers (as opposed to self-published works) were linked to conservative think tanks. ${ }^{195}$

These think tanks and related institutions are significant not merely because of their public impact but because of the way that they advantage some types of conservative views over others. For instance, the theory that large tax cuts would pay for themselves by fueling immense economic growth was based on the work of two then-obscure economists, but their theory received rapid, broad public

189. MCGarity, supra note 152, at 38 (quoting JoHn J. Miller, A GIFT OF FREEDOM 26 (2006)).

190. MAYER, supra note 17, at 106-15.

191. MCGARITY, supra note 152, at 53-54. Switzer also credits "think tanks and research arms of industry interests" for influencing public opinion. SwITZER, supra note 2, at 147 . See also $i d$. at 141 , on the public relations efforts of Heritage. Conservative think tanks also developed links with Congress, playing an important role in Newt Gingrich's Contract with America and the subsequent conservative push in the House of Representatives. MCGARITY, supra note 152, at 52. As with many figures, Gingrich's personal views are more complex than one might expect:

Fascinated with nature and wildlife since he was a boy, Gingrich speaks often of his deep appreciation for the natural world and the importance of protecting the environment for future generations. In Congress, he backed the Endangered Species Act against the wishes of many in his party, and he has spoken out in favor of measures meant to curb global warming.

Sandhya Somashekhar, Gingrich Wild About Zoos, WASH. PoST (Dec. 9, 2011), https://www.washingtonpost.com/politics/2011/12/08/gIQAVb1 yiO_story.html. In a 2008 book advocating expanded oil and gas production, for instance, Gingrich called for "[a] recognition that we have to take seriously the potential risks of climate change and take reasonable steps today to minimize carbon emissions" in a "pro-business and pro-growth way that relies on technology and innovation." Newt Gingrich, Drill Here, DrLl Now, Pay Less: A Handbook for Slashing Gas Prices and Solving Our Energy Crisis 84 (2008).

192. STAHL, supra note 156 , at 17.

193. See Riley E. Dunlap \& Peter J. Jacques, Climate Change Denial Books and Conservative Think Tanks: Exploring the Connection, 57 AM. BЕHAV. SCI. 699, 701 (2013).

194. See id. at 702 .

195. Id. at 706 . 
attention through the efforts of AEI and leading conservative publications. ${ }^{196}$ Conservatives whose ideas fit with the agendas of these institutions had a pathway to influence and potential career opportunities in government that would not be available to conservatives with other points of views. ${ }^{197}$

\section{Environmental Policy and the Reagan Administration}

By 1976, the Republican Party had begun to move toward stressing resource development and introducing balance between environmental and economic values. ${ }^{198}$ By 1980 , the change from Nixon's early embrace of environmental protection was dramatic. The 1980 platform blamed "excessive regulation" for "our Nation's spiraling inflation" and for stifling "private initiative, individual freedom, and state and local government autonomy." "199 It also blamed Democrats for bringing "farmers and ranchers to the brink of disaster and the hardest times they have known since the Great Depression." ${ }^{200}$ In doing so, the platform reflected the backlash in western states against conservation, which was intensified by President Jimmy Carter's alienation of western voters. ${ }^{201}$ In short, the platform said, "Government's power to take and tax, to regulate and require, has already reached extravagant proportions." 202 As an example of the link with the fossil-fuel industry, the platform also emphasized the need to allow for more development of energy resources on public lands and on the Outer Continental Shelf. ${ }^{203}$

During the campaign, the newly anti-environmental Reagan was evident in a number of highly publicized statements" 204 : he promised to start a "total review of thousands and thousands of regulations" and eliminate those imposing costs on industry, small business, farmers, and ranchers. ${ }^{205}$ Echoing the concerns of

196. STAHL, supra note 156 , at 96-97.

197. See id. at 97-98. For instance, Heritage helped place conservatives with key congressional staff. Id. at 126 . According to Stahl, "by late 1985, it was becoming the go-toinstitution for young conservatives who wanted entry into Washington power circles." Id. at 129. I should emphasize that there was nothing illegitimate about these developments; liberals have had their own networks of support.

198. Republican Party Platform of 1976, Am. Presidency Project (Aug. 18, 1976), http://www.presidency.ucsb.edu/ws/?pid=25843 (calling for removal of "counterproductive bureaucratic red tape" to developing oil and other energy resource, fewer barriers to the use of coal, and bringing "the emphasis on environmental concerns ... into balance with the needs for industrial and economic growth").

199. Republican Party Platform of 1980, AM. PrESDENCY ProJeCt (Jul. 15, 1980), http://www.presidency.ucsb.edu/ws/?pid=25844.

200. Id.

201. See SHORT, supra note 175 , at 8-9.

202. Republican Party Platform of 1980, supra note 199.

203. See id.

204. See LAYZER, supra note 25, at 91-92 for examples of Reagan's rhetoric.

205. LAZARUS, supra note 33, at 99. These ideas were congenial to the New Right, a neo-populist conservative movement that had emerged during the 1970s and had ensured the inclusion of similar ideas in the 1976 Republican platform. See LAYZER, supra note 25 , at $55-57$. 
Westerners, he called for greater resource development on public lands. ${ }^{206} \mathrm{He}$ particularly emphasized the potential for oil production. ${ }^{207}$ Late in the campaign, he formed an advisory group led by state environmental law directors and included former Republican EPA heads Russell Train and William Ruckelshaus as counterweights. ${ }^{208}$ However, the immediate influence of this group was limited, and Reagan's campaign statements provided a better forecast of his actions immediately upon taking office.

The extent of Reagan's victory took everyone by surprise because the polls had showed a much closer election, and the election also gave Republicans control of the Senate for the first time in almost 30 years. ${ }^{209}$ After Reagan's unexpectedly large victory, ${ }^{210}$ a different set of advisors emerged, fueled by support from the business community and think tanks such as AEI and Heritage. ${ }^{211}$ The group was led by Ike Livermore (Reagan's environmental advisor from California) but contained a mix of members, some with environmental experience but others with links to conservative politicians or think tanks, ${ }^{212}$ in particular Heritage, which had issued blueprints for the Reagan Administration. ${ }^{213}$

206. See SHORT, supra note 175 , at 42 .

207. See id. at 44.

208. See HAYS, supra note 25, at 492. Details on the group can be found in Reagan Criticizes Clean Air Act, EPA, Announces New Environmental Task Force, 11 ENV. REP. 811, 812 (Oct. 17, 1980).

209. Barton I. Kaufman \& Scott Kaufman, The Presidency of James Earl CARTER 246 ( 2 d ed. 2006).

210. The scale of the victory was considered "a shocker." STEVEN F. HAYWARD, The AGE OF REAGan: THE CONSERvative CounterRevolution, 1980-1989, at 21 (2009). Hayward says that "[f] or movement conservatives, Reagan's election was a golden moment whose like shall never come again." Id. at 24. (Arguably, such a moment actually did come again with the 2016 election, but opinions may differ depending on whether Trump is considered a conservative.) Hayward also notes that, " $[w]$ ith the population shifts to the Republican-leaning Sunbelt states, there was starting to emerge talk of a Republican 'lock' on the electoral college and, therefore, the presidency." Id. at 33.

211. See HAYS, supra note 25, at 492-93.

212. Seven-Member Team Appointed to Manage Change to Reagan Administration at EPA, 11 Envtl. Rep. 1226 (Dec. 12, 1980). According to the report, the team's function was to assemble information rather than make policy decisions. Id. at 1226 . Notably, the team leader for Heritage's report on EPA was in charge of EPA's budget. Id. This turned out to be a crucial tool for the Reagan Administration. In the view of political scientists, "[o]ne of the most distinguishing features of the Reagan presidency is the extent to which the budgetary process was used to achieve goals of policy change." Michael E. Kraft \& Norman J. Vig, Environmental Policy in the Reagan Presidency, 99 POL. SCI. Q. 415,430 (1984).

213. LAZARUS, supra note 33, at 100 . Heritage struck a note of alarm, claiming that regulation had "added to inflationary pressures, reduced productivity, discouraged new investment, and increased bureaucrats' intrusion into everyday life"; the situation was so bad that "regulation threatens to destroy the private competitive free market economy ...." LAYZER, supra note 25, at 87. 
Reagan's actions in the first few years of his presidency were strikingly at odds with his actions as governor. ${ }^{214}$ The familiar story about the Reagan Administration posits a whole-hearted ideological attack on regulation followed by strategic retreat. But the reasons for Reagan's actions are not so clear. Perhaps he was influenced by different groups of advisors during the relevant time periods, ${ }^{215}$ or he believed the pendulum had swung too far in the other direction at the federal level, or he was responding to the difference between California politics and the need to assemble a national conservative coalition.

Whatever the reasons, the first wave of Reagan appointments was dominated by his new advisors, ${ }^{216}$ rather than by the earlier environmental task force. ${ }^{217}$ Candidates to head the EPA were asked during interviews whether they were willing to bring the agency to its knees, ${ }^{218}$ and lower-level appointees were screened by a former Heritage staffer, among others. ${ }^{219}$ New appointees were a combination of industry representatives, western conservatives, and leaders of conservative think tanks. ${ }^{220}$ One of the most controversial appointments, James Watt as Secretary of Interior, ${ }^{221}$ seems to have been something of a fluke. Reagan had agreed to let a key Senate supporter from Nevada make the choice, and the Senator's more moderate first choice had declined. ${ }^{222}$ Watt was a close ally of the Sagebrush Rebellion, ${ }^{223}$ but created something of a backlash, ${ }^{224}$ which finally led

214. See CANNON, supra note 102 , at 196.

215. See LAYZER, supra note 25, at 91.

216. See HAYS, supra note 25, at 492. According to Hayward, the transition was exceptionally well coordinated due to the recognition that "[p]ersonnel is policy," leading to a sharp focus on filling key administrative positions. HAYWARD, supra note 210 , at 37 .

217. See Kraft \& Vig, supra note 212 at 423.

218. LAZARUS, supra note 33, at 101.

219. Kraft \& Vig, supra note 212, at 427. A number of appointees were executives from polluting industries or were connected with James Watt, Reagan's controversial initial appointment to head Interior. See id. According to one historian, "to find out what the Reagan administration wanted to do in detail, it was necessary to buy just one book: Mandate for Leadership," a publication by Heritage. HAYWARD, supra note 210, at 47.

220. See HAYs, supra note 25, at 493-94.

221. For background about Watt, see SHORT, supra note 175, at 40-54. See generally $i d$. at 55-80 for a discussion of Watt's policy views and rhetoric.

222. CANNON, supra note 102, at 319-20. This seems to have been a deviation from normal procedures, where Reagan was given a list of three possible candidates for each position. HAYWARD, supra note 210, at 38. Watt was also supported by Joseph Coors, a prominent campaign contributor. Kraft \& Vig, supra note 212, at 423. Hayward views Watt as a "notable exception to the seeming moderation of the candidate." HAYWARD, supra note 210 , at 42 . Anne Gorsuch at the EPA, though not technically a cabinet appointment, was also a strong critic of environmental regulation and, perhaps more importantly, was deeply loyal to Reagan. See LAYZER, supra note 25, at 101. Other subcabinet appointments were also strongly connected with anti-regulatory activities. $I d$. at 102. David Stockman, the head of OMB, maintained that "a whole new mindset was needed at EPA" lest the agency "practically shut down the economy." Id. at 103.

223. TURNER, supra note 25, at 233. 
to his dismissal after a speech denigrating minorities. ${ }^{225}$ Reagan used his first inaugural address to reiterate his opposition to regulation, announcing that "government is not the solution to our problems, government is the problem."226 Yet he was able to accomplish little in terms of regulatory reform in Congress. ${ }^{227}$

The policy initiatives of these initial appointees received little support, even from industry, which viewed them as a source of regulatory uncertainty. ${ }^{228}$ Little more than two years into Reagan's first term, these officials had become too controversial, and Reagan moved to replace them with more moderate, professional appointees, ${ }^{229}$ while abandoning efforts to pass reform legislation through Congress. ${ }^{230}$ His first appointment to head the EPA, Anne Gorsuch Burford, had been an anti-regulatory ideologue who was forced out after a couple of years. ${ }^{231}$ She was replaced by William Ruckelshaus, an experienced hand who restored agency credibility; he was replaced in turn by a career civil servant who "was careful to maintain the agency on the even keel that Ruckelshaus had set ...."232 At the Interior Department, Watt (who had come from Heritage) was forced out, and his replacement diligently maintained a lower profile..$^{233}$

Thus, Reagan revamped his approach when the initial anti-environmental initiatives ran into trouble. ${ }^{234}$ In the end, he accepted a considerable number of new protections for the environment. He went along with significant environmental legislation from Congress, toughening regulation of hazardous waste and requiring public disclosures of the use and discharge of toxic chemicals. ${ }^{235} \mathrm{He}$ signed

224. See id. at 237. Indeed, the effect was seemingly to push public opinion in a more environmentalist direction. See SwITZER, supra note 2, at 8.

225. CANNON, supra note 102, at $321 \mathrm{n}$.*. Most importantly, Watt had lost the support of key conservative allies in the Senate. SHORT, supra note 175, at 65.

226. See MCGARITY, supra note 152, at 72.

227. He did, however, accomplish one long-lasting regulatory reform through executive order. In his first week in office, he signed Executive Order 12,291, which required systematic use of cost-benefit analysis in designing new regulations. 46 Fed. Reg. 13,193 (Feb. 17, 1981). Section 2 directed that major regulations not be promulgated unless, "taking into account affected industries [and] the condition of the national economy," the potential benefits to society outweigh the potential costs and net benefits are maximized. $I d$.

228. LAZARUS, supra note 33, at 104.

229. See HAYS, supra note 25, at 520-21.

230. For a postmortem on these events, see Blaine Fielding, The Environmental Interregnum -It's Over, 1 ENVTL. FORUM 10 (June 1983). Fielding blames inexperienced, overly ideological appointees for bungling what might have been "[a] real opportunity to correct real excesses in hastily enacted programs." Id. at 12.

231. See MCGARITY, supra note 152, at 103. Gorsuch was the mother of the current Supreme Court Justice.

232. See id.

233. See LAZARUS, supra note 33, at 105.

234. See id. (" $[\mathrm{M}]$ uch of the last six years of the Reagan administration and the first two years of the subsequent Bush administration were marked by efforts by those administrations to distance themselves from the debacle of the first two years of the decade.").

235. LAZARUS, supra note 33, at 110-11. 
numerous wilderness bills, which designated more than ten million acres of wilderness, despite his administration often opposing the bills prior to passage. ${ }^{236}$ During the Reagan years, "Congress did not roll back a single substantive statutory protection, and in 1984 and 1986 it expanded the protections afforded by two hazardous waste control and cleanup statutes." 237 Congress also passed the Commercial Motor Vehicle Safety Act in 1986 and the Rail Safety Improvement Act in 1988.238

Reagan did not merely acquiesce in expansions in environmental protection: on at least one major occasion during his Presidency, he championed it. Reagan himself took a strong position in favor of regulating ozone-destroying chemicals. He signed the Montreal Protocol to protect the ozone layer, expressing great enthusiasm about this effort at international cooperation on the environment:

The Montreal protocol is a model of cooperation. It is a product of the recognition and international consensus that ozone depletion is a global problem, both in terms of its causes and its effects. The protocol is the result of an extraordinary process of scientific study, negotiations among representatives of the business and environmental communities, and international diplomacy. It is a monumental achievement. ${ }^{239}$

Reagan had taken a personal stand on the issue, siding with the EPA on regulations to phase out ozone-destroying chemicals, over the objections of cabinet members who argued for distributing hats and sunglasses as a cheaper alternative. ${ }^{240}$ In his

236. LAYZER, supra note 25, at 130. Lazarus notes that "Congress enacted none of the Reagan administration's proposals to reduce the various federal environmental and natural resource laws." LAZARUS, supra note 33, at 103.

237. See MCGARITY, supra note 152, at 73.

238. Id. at 150 . In addition, Congress also passed the Emergency Planning and Community Right-To-Know Act, Pub. L. No. $99-499$ (1986), codified at 42 U.S.C. $§ 11001$ et seq., which created a new disclosure system for releases of toxic chemicals.

239. Gerhard Peters \& John T. Woolley, Ronald Reagan, Statement on Signing the Montreal Protocol on Ozone-Depleting Substances, AM. Presidency Project (Apr. 5, 1988), http://www.presidency.ucsb.edu/ws/?pid=35639.

240. LAYZER, supra note 25, at 121. A political scientist provides a more detailed account, which he summarizes as follows:

President Reagan had intervened to referee an executive branch dispute in support of the State Department's position despite significant opposition from his Cabinet and his conservative advisors; it was this strategic choice that allowed the United States to maintain its leading role in negotiating the Montreal Protocol and to forge a reputation as a world leader on the ozone depletion issue. And the President made this key decision only after having been briefed twice by the Secretary of State and after hearing both sides being presented at the Domestic Policy Council, a procedure similar [to] that he had often employed with his "super cabinet" when he had been Governor of California.

Jeffry Burnam, Presidential Leadership on Global Climate Change: Opportunities and Constraints 13 (2013), https://blogs.commons.georgetown.edu/american-government- 
signing statement, he called the Protocol "an important milestone for the future quality of the global environment and for the health and well-being of all peoples of the world." 241

Reagan also signed legislation addressing climate change. In 1983, the EPA warned about the risk of a runaway greenhouse effect, though others in the administration considered this alarmist. ${ }^{242}$ As part of an omnibus bill dealing with the State Department, ${ }^{243}$ the Global Climate Protection Act of 1987 contains congressional findings about climate change, stating that evidence of manmade global warming exists and that warming could harm agriculture, render parts of the world uninhabitable, and cause rising sea levels. ${ }^{244}$ The law goes on to state that "[n]ecessary actions must be identified and implemented in time to protect the climate," and it both calls for international agreement and requires the president to "present a coordinate national policy on global climate change" to Congress. ${ }^{245}$ In the House, conservative stalwart James Sensenbrenner said he "support[ed] the development of a coordinated national policy so this country can continue its effective participation with other nations to address this important issue."246

The 1987 Global Warming Act grew out of the summit between Reagan and Mikhail Gorbachev earlier that year. The two leaders agreed they would "continue to promote broad international and bilateral co-operation in the increasingly important area of global climate and environmental change." ${ }^{247}$ In the floor discussion of the Act, Senator Mitchell made note of the fact that the issue was discussed at the summit and observed that "[t]he significance of the fact that this issue was on the agenda of these two world leaders should not go unnoticed

seminar/files/2013/09/JB-Presidential-Climate-Change-Paper.2.docx (emphasis and citation omitted).

241. Ronald Reagan, Statement on Signing the Montreal Protocol on OzoneDepleting Substances, AM. PRESIDENCY Project (Apr. 5, 1988), http://www.presidency.ucsb.edu/ws/?pid=35639.

242. LAYZER, supra note 25, at 124-25.

243. Foreign Relations Authorization Act, Fiscal Years 1988 and 1989 Pub. L. No. 100-204, 101 Stat. 1408 (1987).

244. Id. $\S 1102(1)-(2)$ (codified as 15 USC $\$ 2001$ note). President Reagan's brief signing statement raises concerns about another part of the omnibus bill but does not mention the climate change provisions. Statement on Signing the Foreign Relations Authorization Act, Fiscal Years 1988 and 1989, at 1547-48, in Ronald Reagan, Public PaPers of the Presidents of the United States (1987).

245. Foreign Relations Authorization Act, Fiscal Years 1988 and 1989, Pub. L. No. 100-204, § 1103, 101 Stat. 1408 (1987). The Reagan Administration also supported creation of the Intergovernmental Panel on Climate Change, ("IPCC"), an international body that reports on climate science, because it thought that the IPCC would be less alarmist than individual scientists. LAYZER, supra note 25 , at 129.

246. ConG. REC., 100th Cong., 1st Sess. 35661 (Dec. 15, 1987).

247. Text of the Joint U.S-Soviet Summit Statement, INT'L ATOMIC ENERGY AGENCY 11 (Dec. 21, 1987), http://www.presidency.ucsb.edu/ws/index. php?pid=33803\&st=climate\&stl=gorbachev (the IAEA's involvement was presumably related to the fact that the primary issue on the agenda was nuclear arms control). 
and the President should know that we appreciate his efforts in this regard." 248 In a letter to the New York Times, the head of a scientific organization called this agreement "[t]he best-kept secret of the Reagan-Gorbachev summit-and potentially the most portentous for global well-being during the $21 \mathrm{st}$ century . . . ."249

Many of today's conservatives might prefer to view as authentic only Reagan's environmental positions during his first presidential campaign and the first two years of his presidency. If so, his actions as governor and after the initial years of his presidency have to be explained away as being purely strategic or reflecting passive deference to advisors. At the very least, however, that seems to be an oversimplification. At times Reagan showed more personal commitment to environmental protection than seemed required for strategic purposes-first as governor (such as the ride to save the Sierra wilderness or his preference for saving eagles at the expense of ranchers' lambs) and then at least occasionally in his proenvironmental actions as president (such as the Montreal Protocol). ${ }^{250}$ His motivations were not necessarily transparent. What we do know is that he showed no particular discomfort in embracing a strongly environmental stance as governor, well after he had become a nationally significant conservative figure, and that having done so did not seem to have prevented him from triumphing as a conservative presidential candidate. ${ }^{251}$

Like Reagan, Goldwater also drew back from his early environmental enthusiasm in the late 1970 s and was particularly negative about the EPA. ${ }^{252}$ Like other westerners, he was opposed to the increasing sway of federal protections for public lands, and he became a leader of the Sagebrush Rebellion and an admirer of Reagan's first Secretary of the Interior, James Watt. ${ }^{253}$ But, as with Reagan, Goldwater's environmental impulses sometimes reemerged. In 1982, he introduced a bill to create a new federal wilderness in Arizona, teaming with the liberal Morris Udall. ${ }^{254}$ Like Reagan, Goldwater was a complex person, "not merely an ideology connected to a warm body."255

248. Remarks of Sen. Mitchell, Cong. REC., 100th Cong., 1st Sess. 35783-84 (Dec. 16, 1987).

249. Thomas F. Malone, Global Climate Project is Summit Bonus, N.Y. TIMES (Jan. 12, 1988), http://www.nytimes.com/1988/01/12/opinion/l-global-climate-project-issummit-bonus-615488.html.

250. See supra text accompanying notes 103-26.

251. See supra text accompanying notes 122-24.

252. See Drake, supra note 91 , at $600-02$.

253. Id. at 603 .

254. Id. at 604 .

255. Id. at 605. Drake continues:

He was also a photographer, a hiker, camper, and boater, a wilderness lover, and a middle-class suburban consumer, with all the anxieties, hopes, and desires those things entailed.... Goldwater was always more complicated, more nuanced in his thinking, than his critics and

Id. perhaps even he himself believed. 


\section{Hardening Anti-Regulatory Views After Reagan}

It is commonplace to speak of the conservative movement's shift toward greater purity, or some might say, steady radicalization. ${ }^{256}$ This shift has been accompanied by stronger connections between voters' self-described ideology and party affiliation: by 2010, under 3\% of liberal Democrats and conservative Republicans voted for candidates of the opposing party. ${ }^{257}$ This dovetails with empirical evidence of greater polarization in Congress, with some social scientists viewing Republicans in particular as moving to more extreme positions. ${ }^{258}$ Indeed, Democratic legislators and Republican legislators, even from similar districts, have diverged sharply. ${ }^{259}$ One reflection of these changes has been a hardening of positions on environmental issues, though the process has been more complex than is often realized. ${ }^{260}$

The trend toward greater polarization actually began in the $1970 \mathrm{~s}^{261}$ and remains strong now. It will be no surprise to anyone following politics that strident anti-regulatory rhetoric is common among leading Republicans today. ${ }^{262}$ For instance, in the 2012 primaries some candidates threatened to eliminate the EPA; others dubbed it the "job killing agency of America." The eventual Republican nominee called the EPA "out of control" and said it was devoted to crushing the private sector. ${ }^{263}$ The "job killing" epithet is also a favorite description of the EPA by the current Speaker of the House. ${ }^{264}$ But despite the rhetoric, environmental

256. DionNE, supra note 43 , at 3.

257. Id. at 118 .

258. See Nolan McCarty, Reducing Polarization: Some Facts for Reformers, Univ. CHI. Legal F. 243, 251 (2015). The smaller ideological movement of the Democratic Party to the left up to that point seems attributable to the increase of minority legislators in majority-minority districts and the departure of southern Democrats from the party. See id. at 251-52; Cynthia R. Farina, Congressional Polarization: Terminal Constitutional Dysfunction?, 115 CoLUM. L. REV. 1689, 1696 (2015).

259. See McCarty, supra note 258, at 254-56, 264 ("Democrats and Republicans represent nearly identical districts in very distinctive ways.").

260. A caveat is in order here. Because of the way the ideological positions of legislators are measured, "it is very difficult to discern whether... increased partisan differences in legislative behavior reflect true ideological changes or simply increased intraparty cooperation and inter-party conflict." $I d$. at 267 . Some shifts may also be due to the need to raise money from small donors, who often are "considerably more ideological and extreme than larger donors." Id. at 275. Thus, it is hard to be sure whether the actual policy views of legislators have changed or only their behavior.

261. See id. at 243-44 (reporting a similar trend at the state level).

262. See Arthur Pugsley, The Myth of EPA Overregulation, 39 ECOLOGY L.Q. 475 (2012). Pugsley argues that this rhetoric of regulatory overreaching is not supported by the facts. For instance, Pugsley found eight post-2008 cases in which federal courts held that the EPA had violated the plain language of the statute (Chevron step 1 rulings), but the only one in which this involved overregulation was a Bush-era feedlot regulation; all others involved underregulation. $I d$. at 483 .

$$
\begin{aligned}
& \text { 263. Id. at } 479 . \\
& 264 . \quad I d .
\end{aligned}
$$


politics since Reagan has followed a complex path rather than a straightforward anti-regulatory lunge.

President George H.W. Bush sought pragmatic environmental solutions, continuing and accentuating the pragmatic shift of the later part of the Reagan Administration. Bush "pressed Congress to enact much-needed amendments" to the Clean Air Act. ${ }^{265}$ Congress also enacted the Oil Pollution Act of $1990 .{ }^{266}$ In addition, Congress passed important new health and safety laws. But by 1994, Bush's "hope to create a conservatism that would consolidate the movement's gains while making concessions to middle-ground opinion on the environment" collapsed in the face of the fiercer anti-regulatory zeal of Newt Gingrich and the Contract with America. ${ }^{267}$

President Bill Clinton took an interest in environmental issues, which are periodically mentioned in his memoirs. ${ }^{268}$ But these are brief statements-none over a few paragraphs in a book of nearly a thousand pages - making it clear that other issues such as foreign affairs and the economy were much higher priorities. After winning control of the House in the 1994 elections, conservative Republicans thought they had a mandate to severely cut regulation, but they were unable to maintain party unity and failed to overcome presidential vetoes of antiregulatory measures. ${ }^{269}$ In this era, there were fewer new laws, but again, the legislation that did get enacted usually favored regulation. ${ }^{270}$

265. MCGARITY, supra note 152, at 101.

266. Id. at 104.

267. See DionNe, supra note 43, at 120-22. Dionne contends that, had the first Bush defeated Clinton, "a consolidated and moderated form of conservatism may well have taken hold." Id. at 157. For more on Gingrich and the Contract with America, see THOMAS E. Mann \& Norman J. Ornstein, The Broken Branch: How Congress is Failing AMERICA AND HOW TO GET IT BACK ON TRACK 64-67, 94, 95, 99 (2006). One provision of the Contract with America was the proposed Job Creation and Wage Enhancement Act including "risk assessment/cost-benefit analysis, strengthening the Regulatory Flexibility Act and unfunded mandate reform to create jobs and raise worker wages." See Contract with America, NAT'L CTR. FOR Public POLICY ReseArCh (1994), http://www.nationalcenter.org/ContractwithAmerica.html. One provision of the bill would have given the Director of the Office of Management and Budget veto power over any major regulation, while also expanding the number of regulations classified as major by an order of magnitude. See Paul R. Portney, The Job Creation and Wage Enhancement Act of 1995 Testimony Prepared for Presentation to Committee on Science U.S. House of Representatives, February 3, 1995, RESOURCES FOR THE FUTURE (1995), http://www.rff.org/files/sharepoint/WorkImages/Download/RFF-CTst-95-portney.pdf.

268. See Bill Clinton, My LIFE 727-28 (establishing Grand Staircase-Escalante National Monument), 736 (support for International Coral Reef Initiative), 769-70 (Kyoto Protocol), 870 (visit to New Zealand to highlight global-warming problem), 888 (new national monuments), 907 (coral-reef treaty), 939 (diesel-fuel regulations), 945 (roadlessnational-forest rule) (2004).

269. KLYZA \& SOUSA, supra note 36, at 3-4.

270. Notably, this development took place despite Republican control of the House during most of the Clinton years and despite the increasingly sharp polarization of environmental views in Congress documented by Richard Lazarus. See LAZARus, supra 
During the 2000 campaign, President George W. Bush took a pragmatic approach to environmental issues, even endorsing the idea of controlling carbon emissions. ${ }^{271}$ After his razor-thin victory in 2000 , his political advisor, Karl Rove, concluded that turnout among conservatives was more important than appealing to moderates, resulting in a sharp turn to the right from Bush's positions during the campaign. ${ }^{272}$ Following an early effort that fizzled out, Bush turned his attention away from new legislation and toward regulatory retrenchment through budgetary and administrative actions. ${ }^{273}$ Nevertheless, there was some new health and safety regulation during his administration. None of the new legislation was earthshaking, but given Bush's conservative stance and Republican control of Congress during most of his term in office, the number of laws that expanded regulation is noteworthy. ${ }^{274}$ Yet Bush ended up satisfying nobody. "[B]y trying to do too much-to mobilize the right at the same time he was trying to build support in the center-he ended up alienating both parts of the center-right alliance he was trying to build." ${ }^{275}$ Activist conservatives blamed Republican defeats in 2008 on Bush's infidelity to conservative dogma. ${ }^{276}$

Conservatives have become tightly wedded to the Republican Party, producing a sharp partisan split. By 2010, Republicans were winning nearly $90 \%$ of conservative votes. ${ }^{277}$ In general, conservative dominance of the Republican Party has sparked fierce opposition to the programs of Democratic presidents, ${ }^{278}$ even though Democratic positions on some important issues, like healthcare, may

note 33 , at 154-55. Lazarus also notes the increasing use of appropriation riders to block or delay executive initiatives. Id. at 159.

271. He abandoned the pledge not long after the election. Elizabeth Shogren, Bush Drops Pledge to Curb Emissions, L.A. TIMES (Mar. 14, 2001), http://articles.latimes.com/2001/mar/14/news/mn-37556.

272. See Dionne, supra note 43, at 3 . A poll commissioned by Rove found that "the true swing, independent part of the electorate ... had shrunk from roughly a quarter of the electorate in the Reagan years to a mere 6 percent in 2000." Dionne, supra note 43, at 187.

273. See generally KLYZA \& SoUSA, supra note 36, at 4.

274. In response to a dramatic railroad accident involving toxic gases, Congress enacted the Hazardous Materials Transportation Safety and Security Reauthorization Act of 2005, which "empowered the agency to issue emergency directives to correct unsafe conditions and practices that presented an 'imminent hazard' to the public." MCGARITY, supra note 152, at 156. A provision of the Bioterrorism Act of 2002 authorized an electronic tracking system for food imports. Id. at 141. The Mine Improvement and New Emergency Response Act ("MINER") increased enforcement powers of mine safety regulators. Id. at 89.

275. See Dionne, supra note 43, at 222.

276. See id. at 231 .

277. See id. at 319 .

278. See id. at 11. This has been accompanied by a series of budget impasses, resulting in sharply escalating confrontations between Democratic presidents and Republican Congresses. See Daniel A. Farber, Racing the Clock: Deadlines, Conflict, and Negotiation in Lawmaking 9-13 (UC Berkeley Pub. Law Research Paper No. 2728895, 2016), http://ssrn.com/abstract=2728895. 
be more conservative than past Republicans' positions. ${ }^{279}$ Epitomizing this opposition was Senate Minority Leader Mitch McConnell's famous comment that his main aim was "for Obama to be a one-term president." 280 After President Barack Obama's victories, the Republican Party was "more than ever dependent on the ballots of conservatives . . .."281 Impatient after decades of pragmatic conservative accommodation, activists are said to have "returned in frustration to the unvarnished and uncompromising version of their creed preached not only by the Arizona senator [Goldwater] but also by groups on the farther reaches of the right" like the John Birch Society. ${ }^{282}$

During Obama's presidency, environmental policy became if anything even more politically polarized. ${ }^{283}$ Still, there were significant glimmers of bipartisan support for the environment, such as the passage of an important amendment to a law regulating toxic substances. ${ }^{284}$ Nevertheless, the overall trend seemed to be toward a more confrontational attitude on environmental issues.

At the end of Obama's term in office, the 2016 Republican platform lambasted an effort to clarify federal jurisdiction over wetlands and streams as a travesty, ${ }^{285}$ spoke of the "Democratic Party's campaign to smother the U.S. energy

279. See DionNE, supra note 43, at 12 . Democrats have also moved left on some issues, but less so than Republicans have moved right. See id. at 12.

280. Id. at 289.

281. Id. at 287 .

282. Id. at 23-24.

283. For instance, according to a 2015 survey:

Democrats overwhelmingly, by eight-to-one, said that the country should do whatever it takes to safeguard the environment while Republicans are almost evenly divided. About seven-in-ten (71\%) Democrats believe stricter environmental laws are worth the cost compared with just $37 \%$ of Republicans. Nearly six-in-ten Republicans (59\%) said stricter environmental laws and regulations have a negative economic impact.

Bruce Drake, How Americans View the Top Energy and Environmental Issues, PEW RESEARCH CTR. (Jan. 15, 2015), http://www.pewresearch.org/key-data-points/environmentenergy-2/. This polarization has been attributed to a combination of "big political money, Democratic hubris in the Obama years[,] and a partisan chasm that grew over nine years like a crack in the Antarctic shelf, favoring extreme positions and uncompromising rhetoric over cooperation and conciliation." Coral Davenport \& Eric Lipton, How G.O.P. Leaders Came to View Climate Change as Fake Science, N.Y. TIMES (June 3, 2017), https:/www.nytimes.com/2017/06/03/us/politics/republican-leaders-climatechange.html?_r=0.

284. See Gina McCarthy, TSCA Reform: A Bipartisan Milestone to Protect Our Health From Dangerous Chemicals, EPA BLOG (June 22, 2016), https://blog.epa.gov/blog/2016/06/tsca-reform-a-bipartisan-milestone-to-protect-our-healthfrom-dangerous-chemicals/; Coral Davenport \& Emmarie Huetteman, Lawmakers Reach Deal to Expand Regulation of Toxic Chemicals, N.Y. TiMES (May 19, 2016), https://www.nytimes.com/2016/05/20/us/politics/toxic-substances-chemicalsenvironment.html?mcubz=1.

285. Republican Platform 2016, at 18, https://prod-static-ngoppbl.s3.amazonaws.com/media/documents/DRAFT_12_FINAL[1]-ben_1468872234.pdf. 
industry," 286 decried an "avalanche of regulation that wreaks havoc across our economy," 287 and called for an immediate end to all federal efforts to address climate change. ${ }^{288}$ In short, it appears that conservative Republicans have doubled down on the positions taken by Reagan in the early 1980s, with little evolution and less flexibility than Reagan himself showed.

As a candidate, President Donald Trump repudiated climate science and pledged to repudiate the Paris Agreement and repeal the Obama Administration's signature climate-change regulation, the Clean Power Plan. ${ }^{289}$ Trump's cabinet nominees have close connections with the fossil-fuel industry, and nearly all have a history of denying the reality of climate change ${ }^{290}$ Most strikingly, he picked a person to head the EPA who had also expressed doubts about the reality of climate change and was best known for suing the EPA to halt climate and air pollution regulations. ${ }^{291}$ Trump more recently announced that he would in fact take the United States out of the Paris Agreement, ${ }^{292}$ and he signed an executive order directing the EPA to reconsider the Clean Power Plan. ${ }^{293}$

Under these circumstances, it may seem foolhardy to expect any conservative support for environmental action to emerge. Yet, as discussed in the next Part, there are some signs that conservatives, or at least some conservatives, could rethink some of these views.

286. Id. at 19.

287. Id. at 21 .

288. Id. at 21-22. The platform also reiterated the call to transfer public lands to the states. $I d$. at 21 .

289. Coral Davenport, Donald Trump Could Put Climate Change on Course for "Danger Zone," N.Y. TIMES (Nov. 10, 2016), https://www.nytimes.com/ 2016/11/11/us/politics/donald-trump-climate-change.html?mcubz=1. For an overview of the use of the existing U.S. air pollution statutes to address climate change, see James Salzman \& Barton H. Thompson, Jr., Environmental LaW AND Policy 163-69 (4th ed. 2014).

290. Brian Kahn, What You Should Know About Trump's Cabinet \& Climate, Climate Central (Nov. 30, 2016), http://www.climatecentral.org/news/trump-cabinetclimate-change-20920.

291. Coral Davenport \& Eric Lipton, Trump Picks Scott Pruitt, Climate Change Denialist, to Lead E.P.A., N.Y. TIMES (Dec. 7 2016), http://www.nytimes.com/ 2016/12/07/us/politics/scott-pruitt-epa-trump.html?_r=0. Pruitt and other Trump cabinet nominees indicated during their confirmation hearings that climate change was not a hoax but that they remained in doubt about the extent of the human role in causing climate change and of the need for government action. Jeremy Diamond, Trump Nominees Say Climate Change is No Hoax, But Still Invite Skepticism, CNN Politics (Jan. 19, 2017), https://amp.cnn.com/cnn/2017/01/17/politics/donald-trump-cabinet-picks-climatechange/index.html.

292. Michael D. Shear, Trump Will Withdraw U.S. From Paris Climate Agreement, N.Y. TIMES (June 1, 2017), https://www.nytimes.com/2017/ 06/01/climate/trump-paris-climate-agreement.html.

293. Donald J. Trump, Presidential Executive Order on Promoting Energy Independence and Economic Growth (Mar. 27, 2017), https://www.whitehouse.gov/thepress-office/2017/03/28/presidential-executive-order-promoting-energy-independence-andeconomi-1. 


\section{EXPloring THE Potential FOR A CONSERVATIVE ENVIRONMENTALIST REVIVAL}

There have always been multiple strands in conservatism, such as the early George Will's view that "conservatism has everything to do with prudent accommodation to perpetually changing social, economic[,] and political landscapes . . . ."294 William F. Buckley created the conservative movement by patching together libertarians, social traditionalists, and anti-communist foreignpolicy hawks. ${ }^{295}$ Additional strands of conservatism also emerged. One strand, known as compassionate conservatism, was represented by Jack Kemp and at times by George W. Bush. ${ }^{296}$ This brand of conservatism added an emphasis on social solidarity and civic values to the dominant strand of free-market conservatism. ${ }^{297}$ More recently, the Tea Party movement stressed economic libertarianism (except as to old-age benefits like Medicare), but also embraced social conservatism on issues like abortion. ${ }^{298}$

In political terms, the alliance between these traditionalists, libertarians, and foreign-policy hawks has become shakier, along with the "sharp class split between the working-class whites who provided Republican candidates with critical support, and the upscale conservatives most interested in low taxes and pro-business regulatory policies - and who financed the party." 299 After the 2012 election, a prescient voting analyst argued that the GOP would need to abandon "some of its more pro-corporate stances" and become more "America first" on trade and immigration, and more populist on economic issues. ${ }^{300}$ These positions became the centerpieces of Donald Trump's victorious campaign for the Republican nomination four years later. ${ }^{301}$

\section{A. A Shifting Economic and Political Base}

There are a number of demographic and partisan trends that may change the political picture in important ways over the next decade or two. ${ }^{302}$ Here, we focus only on factors that relate to conservatives' commitment to rolling back environmental protections.

One such change relates to the fossil-fuel industry. As illustrated by the Koch family, "the extractive industries were almost always allied with the right," 
an alliance strengthened in the George W. Bush Administration. ${ }^{303}$ For instance, the Kochs and other industry members helped launch the American Legislative Exchange Council ("ALEC"), a conservative organization that has been influential in state legislatures. ${ }^{304}$ In turn, conservative organizations supported by those industries reciprocated with attacks on climate science. ${ }^{305}$ The Koch family, whose wealth derives from the oil industry, also created a network of political groups to oppose climate change regulation. ${ }^{306}$ Moreover, promotion of fossil fuels remains a key objective of the Kochs. For instance, one of their groups, Fueling U.S. Forward, is "dedicated to educating the public about the value and potential of American energy, the vast majority of which comes from fossil fuels." 307 According to press reports, this initiative "adds a new dimension to the Kochs" more traditional approach to climate and the environment, which has mainly involved financing research skeptical of climate change, backing pro-oil politicians and ballot initiatives, and fighting incentives for renewable energy, all through a network of charitable and political organizations." 308

Doubtless, interests of the fossil-fuel industry still carry important weight in American politics. But economic changes have seriously weakened part of the fossil-fuel coalition. The coal industry's economic plight is well known. In 2016 , coal production was the lowest since a major strike 35 years ago, and coal use dropped over $25 \%$ from the previous year. ${ }^{309}$ In April of 2016, Peabody Coal filed for bankruptcy, joining most of the other major coal firms. ${ }^{310}$ By 2040 , even

303. DiOnNE, supra note 43 , at 251 . According to journalists investigating the Republican Party's hard-edged position on climate change after Obama, compared to the endorsement of cap and trade by its 2008 candidate, "Republican lawmakers were moved along by a campaign carefully crafted by fossil fuel industry players, most notably Charles D. and David H. Koch, the Kansas-based billionaires who ran a chain of refineries ... as well as a subsidiary that owns or operates 4,000 miles of pipelines that move crude oil." Davenport \& Lipton, supra note 283.

304. MAYER, supra note 17, at 345-46.

305. Id. at 274 .

306. Id. at 313 .

307. Hiroko Tabuchi, Sensing Gains Ahead Under Trump, the Kochs Court Minorities, N.Y. TIMES (Jan. 5, 2017), http:/www.nytimes.com/2017/01/05/ business/energy-environment/koch-brothers-fossil-fuels-minorities.html?emc=edit_th_2017 $0106 \& n l=$ todaysheadlines\&nlid $=15539613 \& \_r=0$. As the title indicates, the specific purpose of the group is to recruit minority support for expanded use of fossil fuels and resistance to renewable energy. $I d$.

308. Id.

309. Lucas Davis, King Coal is Dethroned in the US - and That's Good News for the Environment, ENERGY InST. AT HAAS: ENERGY InST. BLOG (Aug. 22, 2016), https://energyathaas. wordpress.com/2016/08/22/king-coal-is-dethroned-in-the-us-and-thatsgood-news-for-the-environment/.

310. Chris Mooney \& Steven Mufson, How Coal Titan Peabody, the World's Largest, Fell into Bankruptcy, Wash. POST (Apr. 13, 2016), https://www.washingtonpost.com/news/energy-environment/wp/2016/04/13/coal-titanpeabody-energy-files-for-bankruptcy/?utm_term=.7eb942cfb543. The bankruptcy reflected broader economic trends: 
assuming no further changes in government policy, coal is expected to fall further to $15 \%$ of energy consumption, slightly above the level from renewables other than biomass and hydroelectricity. ${ }^{311}$ Moreover, the industry now depends heavily on legacy generation plants, with new plants now relying almost wholly on other energy sources. ${ }^{312}$

Economic weakness goes with political weakness. The coal industry had become politically active on environmental issues early in the 1970s, though it was not always united. ${ }^{313} \mathrm{~A}$ declining industry has fewer workers, which ultimately means fewer voters. When Reagan was elected, there were around 230,000 coal miners in the United States; by 2013 , the number was down to around $80,000 .^{314}$ West Virginia had only 18,000 coal miners in 2014,315 about $1 \%$ of its population. ${ }^{316}$ Former miners and their families may stay loyal to the industry, but over time, the number of those supporters is bound to decline.

The decline of coal also means fewer industry allies. States now differ dramatically in their reliance on coal, ${ }^{317}$ meaning that utilities also differ dramatically in their willingness to serve as surrogates for the coal industry. At the

Peabody sales volume has sagged along with coal prices. In 2015, sales from mining slipped by 7 percent and were down 9 percent from 2011 . The company was forecasting a 13 percent drop in U.S. coal sales, its main market.... Peabody is the latest in a string of coal-company bankruptcies that have also engulfed other industry leaders, including

Id. Alpha Natural Resources and Arch Coal.

311. U.S. Energy Information Administration, Today in Energy: Fossil Fuels Still Dominate U.S. Energy Consumption Despite Market Share Decline, EIA (July 1, 2016), https://www.eia.gov/todayinenergy/detail.php?id=26912.

312. Utilities and independent generators have shifted sharply away from the use of coal:

Almost every watt of new generating capacity is coming from natural gas, wind or solar; the coal industry now employs fewer workers than the solar industry, which barely existed in 2010 . Utilities no longer even bother to propose new coal plants to replace the old ones they retire.

Michael Grunwald, Inside the War on Coal, Politico: THE AgEndA (May 26, 2015), http://www.politico.com/agenda/story/2015/05/inside-war-on-coal-000002\#ixzz4KX7 jfdR5.

313. SwITZER, supra note 2, at 109.

314. Coal and Jobs in the United States, Sourcewatch (June 26, 2015), http://www.sourcewatch.org/index.php/Coal_and_jobs_in_the_United_States\#Total_coalrelated_jobs.

315. U.S. Coal Employment by State, Region and Method of Mining-2014, NAT'L MiNING ASSOC. (March 2016), http://nma.org/wp-content/uploads/2016/08/US-CoalEmployment-by-State-Region-and-Method-of-Mining.pdf.

316. Quick Facts (West Virginia), U.S. CENSus BurEAu, http://www.census.gov/quickfacts/table/PST045215/54 (last visited Oct. 10, 2017).

317. John Muyskens et al., Mapping How the United States Generates Its Electricity, WASH. POST (Mar. 28, 2017), https://www.washingtonpost.com/ graphics/national/power-plants/. Coal accounts for more than half of electricity production in over a dozen states but less than $20 \%$ of generation in nearly half the states. $I d$. 
same time, a recent report shows that the coal industry's own lobbying associations are in decline, indicated by decreasing funding (not surprising given all the bankruptcies) and fewer supporters from other industries. ${ }^{318}$ Economists consider it highly unlikely that changes in environmental regulations can revive the coal industry, and the eastern coal industry is particularly unlikely to be revived. ${ }^{319}$

The economic plight of coal is also linked with strengthening of competitors like natural gas producers and renewables companies. In 2016, for the first time, more Americans were employed in clean-energy jobs than in oil and natural-gas extraction or coal mining. ${ }^{320}$ Tighter regulations of the coal industry are actually in the interests of renewables workers because tighter regulations increase demand for alternative energy sources, and renewable energy firms have a stake in reducing fossil-fuel use for the same reason.

These developments are part of a broader phenomenon. There are positive feedbacks between clean-energy policies and political support for those policies, with the policies fostering a stronger renewable energy industry that then supports even stronger policies. ${ }^{321}$ Thus, "[t] he more green industries form or expand, the stronger coalitions for decarbonizing energy systems become, and the easier it gets to install stronger or more comprehensive regulatory strategies." ${ }^{22}$ As coal grows politically weaker, its renewable competitors get stronger, and their regulatory interests generally oppose those of coal.

The oil industry, while far from showing signs of similar decline, has begun to readjust its views of climate change. The major oil companies acknowledge the reality of climate change, and many endorse the need for government action. ${ }^{323}$ For instance, Shell Oil's website states that $\mathrm{CO}_{2}$ emissions

318. Joe Smyth, Coal's Lonely Lobbyists, Climate InveSTIGATIONS CTR. (Aug. 2016), https://d3n8a8pro7vhmx.cloudfront.net/climateinvestigations/pages/133/attachments/ original/1471319258/Coal's_Lonely_Lobbyists.pdf?1471319258.

319. See Alan J. Krupnick, EnERgy Policy and a Trump Administration 4-5 (Nov. 2016), http://www.rff.org/files/document/file/RFF-PB-16-13_0.pdf.

320. Anna Hirtenstein, Clean-Energy Jobs Surpass Oil Drilling for First Time in U.S., BLOOMBeRG (May 25, 2016), http://www.bloomberg.com/news/articles/2016-0525/clean-energy-jobs-surpass-oil-drilling-for-first-time-in-u-s.

321. Eric Biber, Cultivating a Green Political Landscape: Lessons for Climate Change Policy from the Defeat of California's Proposition 23, 66 VAND. L. REV. 399, 42534 (2013). Notably, there is strong support for renewables among Republican governors of states with large wind power production. See Benjamin Storrow, New Best Friends: GOP Governors and Renewables, E\&E NEws (June 23, 2017), https://www.eenews.net/stories/1060056498.

322. Jonas Meckling et al., Winning Coalitions for Climate Policy: Green Industrial Policy Builds Support for Carbon Regulation, 349 SCIENCE 1170, 1170-71 (2015). For a discussion of how this approach fits into general theories about legislative and agency capture, see Matthew Wansley, Virtuous Capture, 67 ADMIN. L. REV. 419, 466-67 (2015).

323. See Oil Company Positions on the Reality and Risk of Climate Change, Univ. OF Wisc. Oshkosh, DePt. of Envtl. Studies, http://www.uwosh.edu/es/climate- 
must be reduced to avoid serious climate change. ${ }^{324}$ According to Shell, government action is needed, and Shell supports an international framework that puts a price on $\mathrm{CO}_{2}$, encouraging the use of all $\mathrm{CO}_{2}$-reducing technologies. ${ }^{325}$ Turning to U.S. oil companies, ConocoPhillips contends that an effective climate policy should involve a binding international agreement, "result in stabilization of GHG [greenhouse gas] concentrations at safe levels", and "utilize market-based mechanisms." 326 Meanwhile, the CEO of ExxonMobil (later Trump's Secretary of State), has said that "for many years ExxonMobil has held the view that the risks of climate change are serious and do warrant action." 327 ExxonMobil assumes a price for carbon in assessing new projects, which need to make economic sense even assuming a high carbon price ${ }^{328}$ No one could accuse these companies of

change/oil-company-positions-on-the-reality-and-risk-of-climate-change (last visited Oct. 10, 2017).

324. Climate Change and Energy Transitions, SHELl Global, http://www.shell.com/sustainability/environment/climate-change.html\#vanityaHR0cDovL3d3dy5zaGVsbC5jb20vZ2xvYmFsL2Vudmlyb25tZW50LXNvY21ldHkvZW5 2aXJvbm1lbnQvY2xpbWF0ZS1jaGFuZ2UuaHRtbA (last visited Oct. 10, 2017). The website adds:

Today, Shell is still primarily an oil and gas company, but we have a long tradition of innovation. We know that long-term success depends on our ability to anticipate the types of energy and fuels people will need in the future and remain commercially competitive and environmentally relevant....

Id. Shell is a long-time supporter of government-led carbon "pricing" mechanisms. Id. 325. Id.

326. Climate Position Paper, ConocoPhlllips (Feb. 2016), http://www.conocophillips.com/sustainable-development/our-approach/Documents/ Climate\%20Change\%20Position_FINAL.pdf.

327. Christopher Helman, What I Learned at ExxonMobil's Annual Meeting, FORBES (May 25, 2016), http://www.forbes.com/forbes/ welcome/?/sites/christopherhelman/2016/05/25/in-dallas-with-exxons-rex-tillerson-and-theanti-carbon-crowd. The CEO also said that the company shared the Intergovernmental Panel on Climate Change ("IPCC") view on climate science. Id.

328. Id. Indeed, Exxon recently appointed a climate scientist to its board of directors. Exxon Mobil Appoints Climate Scientist to Board of Directors, GREENWIRE (January 26, 2016), https://www.eenews.net/greenwire/2017/01/26/stories/1060049027. Similarly, BP has an internal carbon-trading system. Sarah E. Light, The New Insider Trading: Environmental Markets within the Firm, 34 StAn. EnvTL. L. REv. 3, 31-37 (2015). There are also signs that groups whose livelihoods depend on nature, such as farmers, are beginning to take shifts in weather patterns and related risks seriously, even if they still shy away from the term climate change. See Hiroko Tabuchi, In America's Heartland, Discussing Climate Change Without Saying 'Climate Change,' N.Y. TIMES (Jan. 8, 2017), https://www.nytimes.com/2017/01/28/business/energy-environment/ navigating-climate-change-in-americas-heartland.html. Exxon, BP, and other major corporations have also supported a proposal to institute a carbon tax. Dino Grandoni, Exxon, GM and Pepsi Plan to Back Carbon Tax Floated by Ex-GOP Officials, WASH. POST: THE ENERGY 202 (June 20, 2017), https://www.washingtonpost.com/news/ powerpost/paloma/the-energy-202/2017/06/20/the-energy-202-exxon-gm-and-pepsi-planto-back-carbon-tax-floated-by-ex-gop-officials/5947e0eae9b69b2fb981dd82/?utm_term=.4c $01 \mathrm{~b} 10 \mathrm{e} 81 \mathrm{a} 8$. 
being environmental pioneers, but their views are more progressive than those of many conservatives.

As these changes in the energy industry are taking place, changes are also transpiring in what used to be a reliably solid geographic base for antienvironmental views. Recall that much of the impetus for the anti-environmental shift of the 1980 s regarding public lands came from western states. ${ }^{329}$ As early as Reagan's 1980 campaign, growing reliance on voters in the Rocky Mountain West pushed Republicans more strongly toward supporting resource exploitation over preservation. ${ }^{330}$ Today, politics in the Mountain West are shifting, a change reflected in the stances taken by the two major parties. ${ }^{331}$ They are placing their bets on two different visions of the future of the West - one seeing a future based on primary industries like mining, oil, and logging; the other seeing a future based on outdoor activities, real-estate amenities, and clean technology. It remains to be seen which vision will prevail, ${ }^{332}$ but it does seem clear that the Mountain West will be less monolithically pro-development and anti-environmental than in the past.

The two parties are appealing to different western constituencies, with the Democrats hoping to benefit from a shift in the demography and economies of western states. ${ }^{333}$ These contesting views are relevant for our purposes because anti-environmental views in the West were important in shifting conservative politicians like Reagan in that direction, and because "the West has played an important supporting role in the consolidation of Republican political power in national politics." 334

Growth patterns and economics in the West have changed markedly since Reagan left office. ${ }^{335}$ In the 1990s, the West experienced "dramatic new investment and growth," but unlike previous resource-based booms, this one was fueled by a "diverse set of high-tech, telecom, and service industries" while "the most extractive industries lost jobs." 336 Employment in extractive industries remained constant, while employment in other sectors rose dramatically. ${ }^{337}$ Business growth was partly based on the amenities available to attract

329. See supra text accompanying notes 198-208 and 250-55.

330. KLYZA \& SOUSA, supra note 36 , at 21.

331. See infra text accompanying notes 335-50.

332. Even in the Reagan era, there was a split between western cities and rural interests on environmental issues. See SHORT, supra note 175, at 116-17.

333. The political implications of shifts in the demography and economy of the Mountain West are the subject of AMERICA's New SwIng REgION: CHANGING POLITICS AND Demographics In the Mountain West (Ruy Teixeira ed., 2012) [hereinafter Changing MOUNTAIN WeST].

334. TURNER, supra note 25, at 225.

335. See William R. Travis, New Geographies of the American West 1-2 (2012).

336. Id. at 26.

337. Thomas Michael Power \& Richard N. Barrett, Post-Cowboy ECONOMICS: PAy AND PROSPERITY IN THE NEW AMERICAN WeSt 53-57 (2001). 
employees-an "amenity gold rush" including the western landscape. ${ }^{338}$ Correspondingly, rather than being seen as limiting growth, "the West's large swaths of public lands and its dramatic mountain, canyon, and desert terrain now attract and encourage development," while "[n]ewcomers ... cite the West's landscape and outdoor lifestyle as reasons for locating there." 339 These changes have been accompanied by demographic shifts, including an increase in the proportion of college-educated whites. ${ }^{340}$ Current public attitudes in the West emphasize environmental values, outdoor recreation, and strong support for renewable energy. ${ }^{341}$

To date, the Republican Party has steadfastly ignored these changes. The 2016 GOP platform ${ }^{342}$ called for expanded exploitation of public lands, and it advocates narrowing the Endangered Species Act and limiting the president's power to create new national monuments. ${ }^{343}$ Continuing a theme dating back to the Sagebrush Rebellion of the 1980s, the platform also proposed ending federal control of public lands. ${ }^{344}$ The 2016 platform demanded that Congress "immediately pass universal legislation providing for a timely and orderly mechanism requiring the federal government to convey certain federally controlled public lands to states." 345 Another plank of the platform called for state control of oil drilling and coal mining on public lands. ${ }^{346}$ Even better, the platform says,

338. TRAVIS, supra note 335 , at 22. Travis quotes a journalistic account saying that "[t]he Rockies' new ethos manages to combine the yearning for a simpler, rooted, front-porch way of life with the urban-bred, high-tech worldliness of computers and modems." Id. at 25.

339. Id. at 31. In general, "New West theorists believe that landscape amenities now have a large effect on where people and jobs locate, and that development proponents, when they finally internalize this paradigm, will work to protect environmental as well as economic amenities." Id. at 53.

340. Ruy Teixeira, Introduction: America's New Swing Region, in CHANGing MOUNTAIN WEST, supra note 333, at 5.

341. Karyn Bowman \& Ruy Teixeira, The Mountain West Today: A Regional Survey, in Changing Mountain West, supra note 333, at 126-27, 141. Bowman and Teixeira report:

One of the defining characteristics of the Mountain States region in our survey was the belief that people in the region were more likely to engage in outdoor activities and recreation than people in other areas. . . . In addition, 61 percent said that residents of the region were more likely than residents of other regions to make environmental protection a top priority.

$I d$. at 141 . Moreover, $75 \%$ saw support for renewable energy as a defining characteristic of the region. $I d$.

342. Republican Platform 2016, REPUBLICAN NAT'L CONVENTION (July 18, 2016), https://prod-cdn-static.gop.com/media/documents/DRAFT_12_FINAL[1]-ben_146887223 4.pdf/.

343. Id. at 19-22.

344. See id. at 21. The Sagebrush Rebellion also emphasized states' rights. $I d$. TURNER, supra note 25, at 193, illustrates a congenial approach for conservatives.

345. Republican Platform 2016, supra note 342, at 21.

346. Id. at 19 
would be transferring public lands to private ownership. ${ }^{347}$ Apart from resource exploitation, the only other uses for public lands that are mentioned (briefly) in the platform are "hunting, fishing, and recreational shooting." 348

In contrast, the Democratic vision reflected a strong emphasis on the nonresource uses of public lands. This may reflect not just interest by the party's urban base in recreational use, but also the possible transition to a new western economy - one that views public lands as an asset for tourism and as enhancing real-estate values, as much as a source of extractable resources. One study shows that New West counties - those where there are many jobs in tourism, recreation, and tech-were far more likely to vote for Obama in 2012 than those in the Old West, where primary production such as mining and ranching dominated. ${ }^{349}$ As a result, several states that had not voted for a Democrat for two decades voted for Obama twice. The change has been attributed to

ongoing processes that have dramatically increased the [racial and ethnic] minority share of the region's population, brought in millions of new residents from outside the region, raised educational levels, replaced older with younger generations, and powered the rise of dynamic metropolitan areas where the overwhelming majority of the Mountain West population now lives. ${ }^{350}$

The Democratic platform speaks directly to this New West population. ${ }^{351}$ It calls for an American Parks Trust Fund, ${ }^{352}$ adding that "Democrats are committed to doubling the size of the outdoor economy, creating nearly hundreds of billions of dollars in new economic activity and millions of new jobs." 353 The platform also promises to phase down fossil-fuel extraction on public lands and to expand renewable energy on federal lands. ${ }^{354}$

347. Id. at 20 .

348. Id. at 21 .

349. See Benjamin Schultz, The Rise of the New West, CityData.com Blog (Nov. 24, 2015), http://www.city-data.com/blog/592-rise-new-west-2/.

350. Teixeira, supra note 340 , at 1 .

351. 2016 Democratic Party Platform, Democratic Platform Comm. (July 9, 2016), http://s3.amazonaws.com/uploads.democrats.org/Downloads/2016_DNC_ Platform.pdf.

352. Id. at 26

353. Id.

354. Id. at 27. Hillary Clinton's website was even more explicit in addressing the New Western Economy, For instance, she pledged to "ask the Small Business Administration (SBA) to dedicate a portion of SBA loans to entrepreneurs seeking to launch small businesses in the outdoor industry as well as existing business owners in gateway communities." Hillary Clinton's Plan for Conservation and Collaborative Stewardship of America's Great Outdoors, HillaRYClinton.COM, https://www.hillaryclinton.com/ briefing/factsheets/2016/06/01/hillary-clintons-plan-for-conservation-and-collaborativestewardship-of-americas-great-outdoors/ (last visited Oct. 10, 2016). She also says she would "designate outdoor recreation cluster communities where federal agencies will work in partnership with community and business leaders to improve outdoor recreation 
In short, in terms of both energy policy and public lands, the Republican Party currently seems to be holding fast to the positions staked out by Reagan in the early 1980s when development interests were more powerful in western states and the coal industry was a powerful force nationally. The problem with ceding the New West to the Democrats is that these policies, whatever their merits, are geared to interest groups whose relative importance is declining. However convenient coal miners may be as anti-regulatory poster children, their industry has been withering. Meanwhile, the oil industry is holding its own, but has adopted less anti-environmentalist views than the Republican Party. The Democrats, in contrast, seem to be gearing their appeal to interest groups in new energy industries and new aspects of the Western economy. This raises some serious questions about whether western support will remain as politically important to the Republican Party in the future or as rich a source of funding for conservative think tanks.

Perhaps the Republican Party will shift to compete for some of the emerging sectors that are currently targeted by the Democrats. Or perhaps the Republican Party will keep its focus on its traditional sources of support in the West, but compensate by shifting its emphasis to other parts of the country as the strength of those traditional western supporters wanes. Either of these changes would weaken the pressures on conservatives to adhere to traditional positions on energy and environment to maintain access to the networks of influences discussed earlier. Similarly, fossil fuels and other extractive industries are likely to remain important sources of support for the party and for conservative institutions generally, but they may be a weaker source of pressure toward anti-environmental positions than in the past.

\section{B. Straws in the Wind? Signs of Conservative Environmentalism}

One indication of possible shifts in conservative views of the environment came in the 2016 presidential campaign, when Libertarian Party candidate Gary Johnson endorsed the idea of a fee on carbon emissions. His plan for what he called his free-market approach to climate change, "would include a fee-not a tax," placed on carbon. ${ }^{355}$ Only a few days later, Johnson hastily retreated under fire from conservative supporters, with the weak excuse that a few days of additional thought had convinced him that a carbon fee would be difficult to implement. ${ }^{356}$ Still, the fact that the libertarian candidate had endorsed the carbon

infrastructure, attract visitors, new businesses, and workers, and promote the area for its outdoor amenities." Id.

355. James Brooks, Third-Party, First Pick? Gary Johnson Addresses Alaskan Issues in Interview, JUNEAU EMPIRE (Aug. 21, 2016), http://juneauempire.com/state/201608-21/third-party-first-pick-gary-johnson-addresses-alaskan-issues-interview.

356. Michael Bastasch, Gary Johnson Retreats, No Longer Backs A Carbon Tax, DAILY CALLER (Aug. 29, 2016, 9:54 AM), http://dailycaller.com/2016/08/29/gary-johnsonretreats-no-longer-backs-a-carbon-tax/. Some sense of embarrassment at the sudden shift seems to come across in Johnson's explanation:

"We were looking at-I was looking at-what I heard was a carbon fee which from a free-market standpoint would actually address the issue and cost less," Johnson told New Hampshire voters Thursday. "I have 
tax at all is a notable development. The support of a property-right-oriented group, the Property and Environment Research Center, for market-based adaptation to climate change is also notable. ${ }^{357}$

One motivation for rethinking may be a shift in public attitudes. Younger Americans are becoming increasingly likely to identify themselves as liberals, and by 2014 , over half of all conservatives were over $50 .{ }^{358}$ In part to appeal to younger voters, reform conservatives have called for a retooling of conservative thought. $^{359}$ This type of conservatism has some affinities with the views of John McCain, the 2008 Republican candidate, who supported cap and trade for carbon emissions. ${ }^{360}$ Some of the leaders in this effort have been David Frum and Ross Douthat. ${ }^{361}$ These conservatives tend to worry about the stress placed on families by the unconstrained market, especially working-class families. ${ }^{362}$ Frum, in particular, has called for greater attention to environmental concerns by Republicans. ${ }^{363}$

These reform conservatives have rejected denial of climate science as a tenable conservative position, but have not yet identified policy alternatives. Douthat recognizes that climate change is a problem but argues that it should not be a priority under current economic conditions. ${ }^{364}$ Michael Gersen, another reform conservative, argues that "[c]onservatives can choose their policy reactions but not their own reality," and need to identify conservative response to the reality of climate change. ${ }^{365}$ Similarly, conservative commentator Jennifer Rubin, in discussing a proposal for a carbon tax, writes that "a reasoned argument on what sort of response is warranted and a cost-benefit analysis of various approaches is

\footnotetext{
determined that, you know what, it's a great theory but I don't think it can work, and I've worked my way through that."

Id.

357. See Matthew E. Kahn, Climatopolis Revisited: How Free Markets and Urban Growth Facilitate Climate Change Adaptation, PERC Report, Winter 2016-17 (Dec. 16, 2016), http://www.perc.org/articles/climatopolis-revisited. For an overview of PERC's perspective, see Jonathan H. Adler, Introduction to Ecology Liberty and Property, COMPETITIVE ENTER. INST. (June 5, 2000), https://cei.org/op-eds-and-articles/introductionecology-liberty-and-property.

358. See DiOnNE, supra note 43 , at 8.

359. See id. at $416-17$.

360. See id. at 418 .

361. See id. at 421-22.

362. See id. at 423-26.

363. See id. at 441 .

364. Ross Douthout, Reform Conservatism and Climate Change, N.Y. Times: OPINION (June 24, 2014), http://douthat.blogs.nytimes.com/2014/06/24/reformconservatism-and-climate-change/?_r=0.

365. Michael Gerson, It's Time for Conservatives to End the Denial on Climate Change, WASH. POST: OPINIONS (June 25, 2015), https://www.washingtonpost.com/ opinions/deniers-must-face-reality-on-climate-change/2015/06/25/f56ae6c2-1 b5d-11 e5-93b 7-5eddc056ad8a_story.html?utm_term=.ec27ae4f5f15.
} 
far better than counteracting liberal hysteria with conservative knownothingness."366

The idea of a carbon tax is also getting a serious hearing among some conservatives. A libertarian foundation has issued an important report advocating such a tax. ${ }^{367}$ Jerry Taylor, the report's author, has impeccable conservativelibertarian credentials. ${ }^{368}$ The report argues that "[clonservative hostility to proposals to address global warming is often stated as a matter of principle - a defense of free markets and private property against unwarranted government regulation," but "those principles would be better served by well-crafted government action." "369 The report also contends that pollution is an invasion of personal and property rights-rights that libertarians are committed to defending. ${ }^{370}$ The report thereby harkens back to earlier conservative support for emission fees, in as early as 1970 when articles in a leading conservative journal advocated this approach to environmental protection. ${ }^{371}$ The carbon tax also has support from the R Street Institute, a spinoff from the Heartland Institute. ${ }^{372}$

\footnotetext{
366. Jennifer Rubin, Climate Change: Liberal Hysteria vs. Right-Wing KnowNothingism, WASH. POST: RIGHT TURN (Nov. 30, 2015), https://www.washingtonpost.com/blogs/right-turn/wp/2015/11/30/climate-change-liberalhysteria-vs-rightwing-knownothingism/?utm_term=.28ale14ad110.

367. Jerry Taylor, The Conservative Case for a Carbon Tax, Niskanen CTR. (2015), http://niskanencenter.org/wp-content/uploads/2015/03/The-ConservativeCase-for-a-Carbon-Tax1.pdf. An earlier argument for a carbon tax can be found in an AEI research paper. Kevin A. Hassett Et AL., Climate Change: CAPS versus TaXes (2007), www.aei.org/publication/climate-change-caps-vs-taxes. The lead author was the AEI's Director of Research for Domestic Policy. Kevin Hassett, AMER. ENTER. InST., https://www.aei.org/scholar/kevin-a-hassett (last visited Oct. 10, 2017).

368. The Center's website describes him as follows:

Taylor spent 23 years at the Cato Institute, where he served as director of natural resource studies, assistant editor of Regulation magazine, senior fellow, and then vice president. Before that, Mr. Taylor was the staff director for the energy and environment task force at the American Legislative Exchange Council (ALEC).
}

About Jerry Taylor, President, NISKANEN CTR., http://niskanencenter.org/about/ (last visited Oct. 10, 2017).

369. TAYLOR, supra note 367, at 27.

370. $\quad I d$.

371. See LAYZER, supra note 25, at 60.

372. See Catrina Rorke, A Carbon Bargain for Conservatives (R. Street Policy Study No. 68, Sept. 2016), http://www.rstreet.org/wpcontent/uploads/2016/09/68.pdf. According to Rorke,

It's time for carbon policy that ignites, rather than restrains, the power of markets. This paper seeks to address key design principles for a carbon policy that would do just that. Rather than the redundant, intrusive policies coming from the White House, this approach would do better to reduce greenhouse-gas emissions and provide more predictability and flexibility for the market. Most importantly, a properly designed revenue-neutral price on carbon would create the impetus to shrink the size of government at a time when it has been growing perpetually. 
The carbon tax may be something of a wedge issue for conservatives because it involves minimal bureaucracy and could be designed so as to avoid increasing the government's fiscal footprint. Arthur Laffer, Reagan Administration economic advisor and originator of the famous Laffer curve, ${ }^{373}$ has also endorsed a carbon tax. As he explains, "We need to impose a tax on the thing we want less of (carbon dioxide) and reduce taxes on the things we want more of (income and jobs)," and a "carbon tax would attach the national security and environmental costs to carbon-based fuels like oil, causing the market to recognize the price of these negative externalities." 374 Notably, this position is consistent with Laffer's earlier views under Reagan, inasmuch as the Reagan Administration created emissions trading systems through EPA initiatives. ${ }^{375}$ On similar grounds, conservative former Representative Bob Inglis also proposes that "we reduce the tax on some form of income we want more of, whether it is corporate income tax, payroll taxes, or personal income tax, and shift that tax to carbon dioxide." 376

Some significant conservative voices within the legal academy also deviate from the stereotypical anti-environmental conservative positions. Richard Epstein, a libertarian law professor who established an intellectual foundation for the property-rights movement, ${ }^{377}$ strongly endorses the public-trust doctrine as

\section{Id. at 1.}

373. Background on Laffer is provided by his biography. Arthur Laffer, UPCLOSED, https://upclosed.com/people/arthur-laffer/ (last visited Oct. 27, 2017).

374. Bob Inglis \& Arthur B. Laffer, An Emissions Plan Conservatives Could Warm To, N.Y. TIMES, (Dec. 27, 2009), http://www.nytimes.com/ 2008/12/28/opinion/28inglis.html. Inglis and Laffer continued to support a climate tax well after the defeat of climate change legislation by Congress. See Nancy Wise, Laffer Proposes Taxing Pollution, Not Income, VAND. Bus. (Spring 2012), https://magazine.owen.vanderbilt.edu/laffer-proposes-taxing-pollution-not-income/. For a survey of the views of other conservatives (primarily economists) who support a carbon tax, see Zachary Shahan, U.S. Carbon Tax "Close to Inevitable," Conservative Leader Proclaims - Moral Disgrace of Ignoring Global Warming Too Strong, ClEANTECHNICA (June 10, 2016), https://cleantechnica.com/2016/06/10/us-carbon-tax-close-inevitableconservative-leader-proclaims-moral-disgrace-ignoring-global-warming-strong/. Moreover, leading conservative economists have now expressed their support for a carbon tax. See Martin S. Feldstein et al., A Conservative Case for Climate Action, N.Y. TIMES (Feb. 8, 2017), https://www.nytimes.com/2017/02/08/opinion/a-conservative-case-for-climateaction.html?mcubz=1. Their proposal had support from former officials in the Reagan and George W. Bush Administrations as well as important business leaders. Id.

375. LAYZER, supra note 25, at 108.

376. Bob Inglis, Putting Free Enterprise to Work: A Conservative Vision of our Environmental Future, 23 DUKE EnvTl. L. \& POL'y F. 247, 249 (2013). A more recent proposal with backing from senior Republican figures, such as former Bush officials and from leading conservative economists, would simply create a fund for redistribution back to the generational population. See The Conservative Case for Carbon Dividends, Clamate LEADERSHIP COUNCIL (Feb. 2017), https://www.clcouncil.org/wpcontent/uploads/2017/02/TheConservativeCaseforCarbonDividends.pdf.

377. MCGARITY, supra note 152 , at 46-47. 
applied to water bodies and rivers. ${ }^{378}$ Illustrating this doctrine with the example of a river, he argues that "no one can treat the river as a dumping ground for private waste" and "no unilateral acts by an individual are allowed to divert or drain the river for private advantage." ${ }^{379}$ For these reasons, he endorses the California Supreme Court's landmark decision in the Mono Lake case, ${ }^{380}$ which held that the city of Los Angeles's established legal right to divert water from a lake had to yield to the public interest in maintaining the lake's ecology. ${ }^{381}$ Epstein also argues that "[a]ny supposed laissez-faire regime that would leave the question of pollution to the 'market' is no more plausible than a laissez-faire regime that assumes that the state need not supply some remedy against other forms of aggression that one individual takes against the rest of the world." 382

Epstein favors a cautious approach to the problem of climate change, in part because of scientific uncertainty. ${ }^{383}$ He would focus on "low-hanging fruit" like controlling methane pollution in order "to buy some more time so that the technology will evolve in ways that make us less dependent on fossil fuels." ${ }^{384}$ His equivocations about climate science are hardly likely to win the approval of environmentalists or scientists. Still, he is less adamantly opposed to climate action than the Republican Party as a whole.

Perhaps the most sustained effort to elaborate a new conservative environmentalism comes from a younger libertarian law professor, Jonathan

378. See Richard A. Epstein, Property Rights and Governance Strategies: How Best to Deal with Land, Water, Intellectual Property, and Spectrum, 14 COLO. TECH. L.J. 181, 185-203 (2016).

379. Id. at 188 .

380. Nat'l Audubon Soc'y v. Super. Ct. of Alpine Cty., 658 P.2d 709 (Cal. 1983).

381. Epstein, supra note 378, at 192-93. Epstein's explication of the case is worth quoting at length:

[T]he challenge that faced California was keeping up the water levels in Mono Lake in the face of diversions of large amounts of water to serve the various metropolitan areas from a saltwater lake that supported substantial populations of brine shrimp, which are in turn the food for the large number of migratory birds that flew over the area. The protection of those birds in turn required the maintenance of islands, which could not be reached by coyotes, their natural predators. When the water levels started to fall, the entire cycle started to implode, so the public trust doctrine was properly invoked ....

Id. at 192. Another conservative effort to rethink the public trust doctrine can be found in Barton H. Thompson, Jr., The Public Trust Doctrine: A Conservative Reconstruction and Defense, 15 SE. EnVTL. L.J. 47 (2006).

382. Richard A. Epstein, Modern Environmentalist Overreach: A Plea for Understanding Background Common Law Principles, 37 HaRv. J. L. \& PuB. POL'y 23, 23 (2014). Epstein calls for "institutional arrangements that call for the constant comparison of the proposed gains from government actions with their losses." Id. at 38.

383. He has developed this position in Richard A. Epstein, Carbon Dioxide: Our Newest Pollutant, 43 Suffolk L. Rev. 797 (2010).

384. Id. at 826. Epstein also calls for eliminating "subsidies that lead to the destruction of forests" and for expansion of nuclear power. Id. at 826-27. 
Adler. ${ }^{385}$ Adler laments that " $[\mathrm{t}]$ he dominant alternative on the political right has been reflexive-almost reactionary-opposition to anything green," characterized by the view that "whatever the Sierra Club or Al Gore supports must be opposed." 386 Indeed, he says, "This reactionary posture has expanded beyond reflexive opposition to environmental policy proposals to encompass a reflexive denial that environmental problems, of whatever sort, actually exist." ${ }^{387}$ Adler also rejects what he calls "me too" conservative responses, whereby conservatives endorse the same solutions as liberals but on a smaller scale and at a slower pace ${ }^{388} \mathrm{He}$ views liberal solutions making use of the federal administrative state as having "produced some gains, but also many failings." 389 Instead, he favors an alternative approach.

Adler's favored approach to environmental protection has several prongs. The first is to eliminate government interventions that actively increase environmental harm, such as subsidies for agriculture (which can encourage environmentally harmful farming practices) and fossil fuels. ${ }^{390}$ Second, Adler argues that measures increasing economic growth will indirectly lead to a cleaner environment-increasing societal wealth will increase support for environmental amenities and capacity to achieve them. ${ }^{391}$ Third, he calls for greater respect for property rights, to encourage landowners to take the long view and invest in conservation, and he advocates the use of new property rights for conservation purposes, such as tradable catch shares to prevent overfishing. ${ }^{392}$ Fourth, he endorses the polluter-pays principle calling for emissions fees to limit pollution including a carbon tax. ${ }^{393}$ Finally, he calls for decentralization, moving more of the responsibility for environmental protection from the federal government to the states. ${ }^{394}$

385. For a sampling of Adler's work, see Jonathan H. Adler, Dynamic Environmentalism and Adaptive Management: Legal Obstacles and Opportunities, $11 \mathrm{~J} . \mathrm{L}$. ECON. \& POL'y 133 (2015); Jonathan H. Adler, Conservative Principles for Environmental Reform, 23 Duke Envtl. L. \& POL'y F. 254 (2013) [hereinafter Adler, Principles]; Jonathan Adler, Free \& Green: A New Approach to Environmental Protection, 24 HARV. J. L. \& PuB. POL'Y 653 (2006); Jonathan H. Adler, Introduction: The Virtues and Vices of Skeptical Environmentalism, 53 CASE W. RES. L. REV. 249 (2002).

386. Adler, Principles, supra note 385, at 256.

387. Id.

388. Id. at $256-57$.

389. Id. at 261.

390. Id. at 266-69.

391. Id. at 269-70.

392. Id. at $271-75$.

393. Id. at 275-78. He views the polluter-pays principle as an application of the conservative principle of personal accountability. Id. at 275 .

394. Id. at 278-80. Adler also calls for a system of prizes to incentivize innovations in energy technology. See Jonathan H. Adler, Eyes on a Climate Prize: Rewarding Energy Innovation to Achieve Climate Stabilization, 35 HARV. ENVTL. L. REv. 1 (2011). Government support for innovations is the focus of the conservative-leaning Energy Innovation Reform Project. Innovation Reform Agenda, ENERGY InNOvAtion ReForm PROJECT, http://innovationreform.org/reform-agenda/ (last visited Oct. 10, 2017). 
Notably, Adler has argued that carbon emissions are a violation of property rights because they lead to loss of land due to sea-level rise ${ }^{395} \mathrm{He}$ argues that,

whether or not current legal institutions would recognize causes of action against human contributions to climate change, and whether or not legal institutions exist that are capable of adjudicating such claims, it seems that some of the predicted consequences of global warming, such as an increase in sea level and consequent flooding, would constitute property-rights violations . . . .396

Thus, he says, the proper libertarian view is that the government has a duty to protect landowners against this violation of their rights. ${ }^{397}$

Adler does not stand alone in proposing a rethinking of conservative positions. Professor Blake Hudson argues, for example, that conservatives should support the use of state and local land-use controls to achieve environmental goals, as a superior alternative to federal regulation. ${ }^{398}$ Professor Shi-Ling Hsu has presented a conservative case for carbon taxation ${ }^{399}$ and argues that conservatives need to ground their approach on current science, including climate science, and on empirical findings about regulatory shortcomings. ${ }^{400}$ Similarly, James Huffman calls for increased decentralization and use of market mechanisms on the theory that " $[w]$ here individuals experience the costs and benefits of their actions-where

395. Jonathan H. Adler, Taking Property Rights Seriously: The Case of Climate Change, 26 Soc. PHIL. \& POL'y 296 (2009). Adler analogizes to traditional rules protecting property owners against interference with waterways. He observes that, under these rules,

[a]ctions that caused downstream flooding, denial of the natural flow of waterways, or other kinds of interference with another landowner's quiet enjoyment of her land could be actionable at common law and would be recognized as infringements upon private property rights by FME [free market environmentalism] proponents even if legal remedies were unavailable.

Id. at 310 .

396. Id.

397. Id. In Adler's view,

[A]s noted above, for the consequences of climate change to constitute property-rights violations, climate change need not be catastrophic, nor must it produce more costs than benefits. All that is necessary is that it impose identifiable harms on those who do not consent to the imposition of such harms, a scenario that even ardent warming "skeptics" acknowledge is likely.

Id. at 312 .

398. See Blake Hudson, Relative Administrability, Conservatives, and Environmental Regulatory Reform, 68 FLA. L. REV. 1661, 1664-67 (2016).

399. Shi-Ling Hsu \& Yoram Bauman, Why Conservatives Should Support a Carbon Tax (Florida State Univ. Law Sch., Public Law Research Paper No. 621, 2012), https://papers.ssrn.com/sol3/papers.cfm?abstract_id=2188945\&download=yes.

400. Shi-Ling Hsu, A Conservative Approach to Environmental Law: Be Data Driven, 23 DuKe ENVTL. L. \& POL'Y F. 281 (2013). 
they have a right to the benefits and are responsible for the costs-we will have the incentives right for environmental protection more often than not." 401

In 2015, the conservative ferment reached the point when it began to receive media attention. In October 2015, the press reported on a Conservative Clean Energy Summit on Capitol Hill. ${ }^{402}$ Addressing the group, Senator Chuck Grassley of Iowa said it was "a privilege for me to be with people who believe that Jesus Christ is their personal savior and who are politically conservative," before going on to advocate more support for renewable energy. ${ }^{403}$

Along with the early embrace of environmental protection by conservative icons such as Reagan, these contemporary figures confirm that conservatism has the intellectual resources to support divergent views of environmental law. Given the waning of some of the pressures that previously cemented the dominance of anti-environmental views among conservatives, these voices could have a greater chance in the long run to establish themselves within the conservative movement.

Donald Trump's election was a surprise to many observers, leaving some reform conservatives to wonder if their movement had a future. ${ }^{404}$ Yet, if nothing else, Trump's victory illustrates the unpredictability of politics. It is by no means clear, as of yet at least, that Trump will succeed in reversing the trends discussed above. Even in an election where Republicans did very well overall, their hold on the West was far from its zenith, with Hillary Clinton winning Colorado, New

401. James L. Huffman, Making Environmental Regulation More Adaptive Through Decentralization: The Case for Subsidiarity, 52 U. KAN. L. REv. 1377, 1399 (2004). For this reason, he seems to favor cap-and-trade programs. See James L. Huffman, Environmental Perspectives: Moving Toward a Market-Oriented Middle Ground, 28 HARV. J. L. \& PUB. POL'Y 61, 64-65 (2004) (advocating use of market tools in situations where regulation is necessary). Huffman's emphasis on the importance of property rights in conservation efforts is echoed by Jonathan Adler. See Jonathan H. Adler, Back to the Future of Conservation: Changing Perceptions of Property Rights and Environmental Protection, 1 NYU J. L. \& LIBERTY 987, 1013-22 (2005).

402. See John Siciliano, Republicans to Rally Around Renewable Energy in D.C., WASH. EXAMLNER (Sept. 19, 2016), http://www.washingtonexaminer.com/republicans-torally-around-renewable-energy-in-dc/article/2602138; Amanda Little, Will Conservatives Finally Embrace Clean Energy?, NEw Yorker (Oct. 29, 2015), https://www.newyorker.com/tech/elements/will-conservatives-finally-embrace-cleanenergy.

403. Little, supra note 402. Tracing the history of environmental thought among evangelicals and other religious conservatives is beyond the scope of this Article, but John Nagle has shown that the anti-environmentalist stereotype is misleading in that setting as well. See John Nagle, The Evangelical Debate Over Climate Change, 5 U. ST. THOMAS L.J. 53, 53-86 (2008); John Nagle, Playing Noah, 82 MinN. L. REV. 1171, 1175-76, 1225, 1229 , 1237 (1998).

404. See, e.g., James Pethokoukis, Conservatives Like Me Wanted to Reform the Republican Party. What Do We Do Now?, Vox (Nov 14, 2016), http://www.vox.com/thebig-idea/2016/11/14/13618962/republican-party-reform-trump-reformicon. 
Mexico, and Nevada, while Trump carried Arizona by only $4 \%$ of the vote, ${ }^{405}$ and Montana reelected a Democrat as governor. ${ }^{406}$

How much Trump's surprise victory will realign American politics, and how it might do so, remain to be seen. Trump's victory was based on extremely slim victories in Wisconsin (a $1.3 \%$ margin), Michigan $(0.3 \%$ ), and Pennsylvania $(0.2 \%)$-victories that may or may not herald a long-term move to Republican control. ${ }^{407}$ Moreover, the history of the Reagan Administration discussed in Section III.B demonstrates that even deeply anti-regulatory administrations can moderate their views over time. ${ }^{408}$ Thus, it is much too early to judge how Trump's unexpected victory will shape the future of the Republican Party or the conservative movement.

In the longer run, Republicans (and conservatives) will face the problem of appealing to younger generations of Americans, who do not share their current orthodoxies. By inexorable demographics, the share of the electorate born in this century will continue to rise, while the number born before 1970 will continue to decline. These trends do not favor the Trump coalition: Clinton beat Trump 55\% to $37 \%$ among millennials, while losing $45 \%$ to $53 \%$ among baby boomers. ${ }^{409}$

Millennials also place much more importance on environmental issues like climate change. Nearly three-quarters of adults under 30 favor restricting carbon emissions from power plants. ${ }^{410}$ Sixty-one percent of this group opposed expanded offshore drilling, as compared with $35 \%$ of the over-65s. Seventy-four percent of the younger group think developing alternative energy sources is more important than expanding fossil fuels. In other words, young voters are much greener than baby boomers. The passage of time will make it politically more difficult to sustain a type of conservatism tied so much to an aging segment of the population.

\section{CONCLUSION}

In politics and political thought, as in weather forecasting, the safest forecast is that tomorrow will probably be much like today. Strong forces have held together a conservative coalition of anti-regulatory businesses and social traditionalists, supported by a network of media outlets, think tanks, and party institutions. At least in the near term, anti-environmental Republicans are likely to maintain control of the House and to have a reasonable prospect of holding the

405. The relevant statistics can be found at 2016 Presidential Election Results, Politico (Dec. 13, 2016), http://www.politico.com/2016-election/results/map/president. 406. See 2016 Governor Election Results, POLITICO (Dec. 13, 2016), http:/www.politico.com/2016-election/results/map/governor.

407. See 2016 Presidential Election Results, supra note 405.

408. Admittedly, there is no sign of that happening as of this writing.

409. See Reality Check: Who Voted for Donald Trump?, BBC NEWS (Nov. 9, 2016), http:/www.bbc.com/news/election-us-2016-37922587.

410. Pew Research Ctr., Americans, Politics and Science Issues 48 (2015), http://assets.pewresearch.org/wp-content/uploads/sites/14/2015/07/2015-07-01_scienceand-politics_FINAL-1.pdf. 
Senate on a regular basis, ${ }^{411}$ and presidential elections are too close in the modern era to lead to comfortable predictions. In the longer run, demographic shifts (including perhaps closer identification of minorities with the Democratic Party unintentionally fostered by Donald Trump) may increase the prospects for a partisan realignment, ${ }^{412}$ which in turn might prompt a rethinking of conservative policy stances. But such predictions about future political configurations are speculative and should be received with caution.

Despite the unlikelihood of any immediate short-term dramatic changes in the dominant conservative views, there are signs that the conservative antienvironmental consensus could be breaking down. As we saw in Part I, today's anti-environmental stance is not a necessary component of conservative thought. Such stalwart conservatives as Ronald Reagan, Barry Goldwater, and William F. Buckley took strikingly different views in the early days of the modern environmental era. These iconic figures apparently saw no contradiction between deeply conservative philosophies and enthusiastic support for environmental protection. Even after changing times pushed them in the other direction, they still showed flashes of environmentalism. Conservatives with reformist views of environmental issues today can thus claim some surprising support from the founding fathers of modern conservatism.

Moreover, as Part III shows, there could be some reduction in the political forces and institutional pressures that have entrenched a particular conservative stance on the environment. Much of the anti-environmentalist pressure on early conservatives came from the fossil-fuel industry and from extractive industries in the western United States. Those pressures could be loosening; as the coal industry's influence declines, the oil industry repositions itself in response to concerns about climate change, and western demographics and economy change. New voices are advancing environmental conservative positions, and these shifts may create more space for them to flourish.

We should not be too quick, then, to identify support for environmental protection too heavily with one end of the ideological spectrum. Greater diversity in conservative views would not only be significant as a possible source of political support for measures such as a carbon tax; it could also free conservatives from ongoing battles with science. ${ }^{413}$ Finally, environmental conservatism would

\footnotetext{
411. See Dionne, supra note 43, at 449.

412. See, e.g., id. at 456-58. As Dionne puts it,

There is a time limit on the ability of conservatism in its current form and Republicanism in its current incarnation to win elections. A movement rooted in a fifty-year-old ideology, dependent on an aging constituency, and closed to the kind of nation the United States is becoming may win short-term victories, but it Id. at $456-57$. will ultimately wither.

413. For a popularized account of this conflict, see CHRIS MOONEY, THE REPUBLICAN WAR ON SCIENCE (2007). Mooney can be criticized for glossing over tensions between some liberal positions and the scientific community, though conservative rejection of climate science has been much more prominent. For a more recent update, see
} 
also enrich a public discourse that has seemingly become trapped in endless battles between ideological opponents; liberal environmentalists could be stimulated to respond to a fresh perspective. In short, both conservatives and liberals have something to gain if the alternative conservative views of the environment-like the views that led to Ronald Reagan's Sierra horseback ride-were once again more prevalent among conservatives.

Regardless of whether such future developments eventually do come to pass, the history of conservative environmental thought has important lessons. There is a temptation to assume that intellectual and political movements have a timeless quality, with fixed perspectives and goals. Recalling the early environmentalism of Buckley, Goldwater, and Reagan is an important reminder of the dangers of such oversimplification. Understanding the reasons why these views were later abandoned gives us insights into how ideologies have developed in the past-and may yet do so in the future. As the 2016 election reminds us, life is full of surprises. Ideologies are not set in stone.

Constantine Boussalis \& Travis G. Coan, Text-Mining the Signals of Climate Change Doubt, 36 Glob. Envtl. Change 89 (2016). 